\title{
CHARCOT AND THE IDEA OF HYSTERIA IN THE MALE: GENDER, MENTAL SCIENCE, AND MEDICAL DIAGNOSIS IN LATE NINETEENTH-CENTURY FRANCE
}

\author{
by
}

\author{
MARK S. MICALE*
}

On concède qu'un jeune homme efféminé puisse après des excès, des chagrins, des émotions profondes, présenter quelques phénomènes hystériformes; mais qu'un artisan vigoureux, solide, non énervé par la culture, un chauffeur de locomotive par exemple, nullement émotif auparavant, du moins en apparence, puisse ... devenir hystérique, au même titre qu'une femme, voilà, paraît-il, qui dépasse l'imagination. Rien n'est mieux prouvé, cependant, et c'est une idée à laquelle il faudra se faire.

Charcot (1885)

Hysteria is among the oldest recorded diagnostic categories of neurosis. Through a long and exotic evolution, the popular and medical understanding of the disorder has changed greatly. However, one feature of hysteria has remained constant: since classical times, hysteria has been understood as an affliction essentially of adult women and adolescent girls. If we know anything about the disorder, we are likely to know that it relates etymologically to the Greek word hystera or uterus. In Graeco-Roman medical literature, hysteria-or at least something that many latter-day commentators have interpreted as hysteria - was believed to develop when the female reproductive system was inactive or ungratified over time. In Plato's Timaeus and certain Hippocratic texts, we find graphic descriptions of the uterus as a restless animal, raging through the female body due to unnatural prolonged continence and giving rise to a bizarre series of symptoms, including a sensation of suffocation, heart palpitations, and loss of voice. In keeping with these beliefs, prescribed treatments for the malady through the years have included massage of the pelvic area, ovarian pressure, the application of scented drugs to entice the uterus back into place, and, perhaps most to the point, immediate marriage. As in so many areas of medicine, classical theory on this subject proved immensely influential, and for millennia hysteria was conceptualized, quite by definition, as a female sickness. ${ }^{1}$

* Mark S. Micale, Ph.D., Dept. of History, Yale University, 320 York St., New Haven CT 06520, USA.

${ }^{1}$ For intellectual histories of the disorder, see Ilza Veith, Hysteria: the history of a disease, University of Chicago Press, 1965; George R. Wesley, A history of hysteria, Washington, D.C., University Press of America, 1979; and Étienne Trillat, Histoire de l'hystérie, Paris, Seghers, 1986. 


\section{Mark S. Micale}

From a distance, the final quarter of the nineteenth century provides no exception to the rule. It was the belle époque of hysteria, and Paris and Vienna, those quintessentially turn-of-the-century cities, its native environments. The image of hysteria in its famous fin-de-siècle phase has been of a phenomenon thoroughly female. This view has been powerfully inscribed in the historical imagination by a number of major documents, which in recent years have received a good deal of scholarly attention. In late nineteenth- and early twentieth-century Britain and America, several middle-class social and literary figures, such as Charlotte Perkins Gilman, Alice James, Eleanor Marx, and Virginia Woolf, recorded their experiences of nervous illness in memorable fictional and autobiographical accounts. In the late $1870 \mathrm{~s}$, Charcot and his circle of students in Paris created dramatic representations of the female hysterical attack in the Iconographie photographique de la Salpetrière. ${ }^{2}$ And, in the following decade, Charcot's work was memorialized further in Andre Brouillet's enormous painting, Une leçon clinique à la Salpêtrière. ${ }^{3}$ Finally, in 1895 , Freud and Breuer published their Studies on hysteria, which included the case histories of "Anna O." and four other hysterical women, the famous proto-patients of psychoanalytic theory.

In the last decade or so, scholarly enquiry into the history of hysteria has increased at a tremendous rate. ${ }^{4}$ The bulk of this writing has been cast in what may loosely be characterized as either feminist or Freudian historiographical moulds. By now, both of these approaches have generated sizeable and significant bodies of work. ${ }^{5}$ However, the focus of investigation in these writings has been specialized. Feminist critics and historians have been concerned centrally with hysteria as a historical experience of women, particularly nineteenth-century middle-class women. Similarly, Freudian scholars have limited themselves to those portions of hysteria's history that contributed directly to the constitution of psychoanalytic theory. Furthermore, both historiographical traditions have tended to rest on a rather slender evidential base, drawing heavily on a handful of well-known documents. Not unexpectedly, hysteria emerges time and again as "the quintessential female malady". 6 The question of the disease and the diagnosis as applied in the past to other patient populations has either been ignored or dismissed as statistically and therefore interpretively of little significance. $^{7}$

2 D.-M. Bourneville and P. Régnard, Iconographie photographique de la Salpêtrière, 3 vols., Paris, Bureaux du Progrès Médical, Delahaye \& Lecrosnier, 1876-80. For a recent book-length study of this source, see Georges Didi-Huberman, Invention de l'hystérie. Charcot et l'iconographie photographique de la Salpêtrière, Paris, Macula, 1982.

${ }^{3}$ Brouillet's canvas was recently the object of a special exhibition in Paris. See the informative catalogue, La leçon de Charcot. Voyage dans une toile, exposition organisée au Musée de l'assistance publique de Paris, 17 September-31 December 1986, Paris, Tardy Quercy, 1986.

${ }^{4}$ For an attempt to account synthetically for the burgeoning historical literature on hysteria, consult Mark S. Micale, 'Hysteria and its historiography: a review of past and present writings', Hist. Sci., 1989, 27: 223-61, 317-51; and idem, 'Hysteria and its historiography: the future perspective', Hist. Psychiat., 1990, 1: 33-124.

${ }^{5}$ For a review of these large literatures, refer to Micale (1989), op. cit., note 4 above, pp. 246-54, 319-31.

${ }^{6}$ Quoted in Elaine Showalter, The female malady: women, madness, and English culture, 1830-1980, New York, Pantheon, 1986, p. 129.

${ }^{7}$ There have been a number of important exceptions: Elisabeth Kloë, Hysterie im Kindesalter: Zur Entwicklung des kindlichen Hysteriebegriffes, Freiburger Forschungen zur Medizingeschichte 9, Freiburg, 


\section{Charcot and the idea of hysteria in the male}

In the present essay, I explore a segment of hysteria's famous history that hitherto has been ignored. If we move beyond a reading of canonical literary and scientific texts to a consideration of the full range of extant original sources, we discover that the late nineteenth century generated a large body of writing on hysterical disorders in men and children. Undoubtedly, the prime mover in this development was Charcot. During the 1880s, Charcot published the case histories of more than 60 male "hysterics" and treated countless others in his daily hospital practice. Between a third and a quarter of the overall number of hysterical patients he presented in his printed works were men or children. In these writings, Charcot formulated an elaborate set of medical ideas about the disease in males, including a theory of aetiology, a model of symptomatology, and a programme of therapeutics. Throughout this period, Charcot campaigned energetically for his theory of masculine hysteria, and by the time of his death, in 1893, the idea was widely accepted within mainstream European medical communities. Many of Charcot's medical contemporaries judged his work on the topic to be among the most scientifically significant parts of his oeuvre, and the School of the Salpêtrière, as it was called, was associated internationally with the theme of male hysteria. Beyond this, Charcot's writings on child and male hysteria were picked up during the last two decades of the century by scores of young doctors and medical students, who produced a large, if repetitive, literature on the subject, totalling over 20 books and dissertations and hundreds of periodical articles in the major European languages. Finally, Charcot's work on the theme of masculine hysteria was part of a broad cultural process occurring in many scientific and non-scientific areas of late nineteenth-century European thought, whereby traditional definitions of masculinity and femininity underwent extensive reformulation.

The fact that Charcot argued for the existence of hysterical illnesses in members of his own sex is often mentioned in present-day histories of psychiatry and psychoanalysis. ${ }^{8}$ However, nowhere do we have a close and complete examination of his ideas and their historical significance, based on the full range of extant original sources. Currently, I am preparing a monographic study of Charcot's work on hysteria in males and its place in late nineteenth-century medical culture. The present essay represents a kind of detailed progress report on that larger project, a preliminary offering of information and ideas. In what follows, I have concentrated overwhelmingly on Charcot's own writings and on the subject of hysteria in adult

\footnotetext{
Hans Ferdinand Schulz, 1979; Elisabeth Kloë and Hildburg Kindt, 'Zur Entstehung und Entwicklung des kindlichen Hysteriebegriffes', Gesnerus, 1981, 38: 281-300; K. Codell Carter, 'Infantile hysteria and infantile sexuality in late nineteenth-century German-language medical literature', Med. Hist., 1983, 27 : 186-96; and Showalter, op. cit., note 6 above, chapter 7. Also, Veith, writing 20 years ago, remained attentive throughout her narrative to the emergence of the idea of hysteria in men.

${ }^{8}$ And we now have a reprint of a selection of his writings on the topic: Jean-Martin Charcot, Lefons sur l'hystérie virile, Paris, S.F.I.E.D., 1984, with an excellent introduction by Michèle Ouerd. See also the cases concerning hysteria in the forthcoming re-issue of Charcot, Clinical lectures on diseases of the nervous system, vol. 3, translated from the French by Thomas Savill (1889), with a historical introduction by Ruth Harris, in W. F. Bynum and Roy Porter (eds.), Tavistock classics in the history of psychiatry, London, Routledge.
} 
men. ${ }^{9}$ The essay divides into six parts: the first section consists of a brief prehistory of the idea of male hysteria from ancient times to the mid-nineteenth century. Part two considers basic matters of bibliography, such as the form, volume, and location of Charcot's writings, as well as the sources of his interest in the subject. The third section discusses the hysterical male patients themselves, emphasizing their social, sexual, and occupational identities. The lengthiest portions of the essay, sections four and five, present in some depth Charcot's ideas regarding the causes, evolution, and symptomatology of hysteria in its masculine forms. The sixth and final part provides a rather more speculative excursus on the social and cultural meaning of Charcot's work. Over the last 20 years scholars of psychoanalysis have educated us in regard to the life and work of Freud, and historians of the nineteenth century have written at length about the ill-health of the bourgeois woman. But other medical figures contributed importantly to the mental sciences of the time and other populations, including children and working-class men, were fully implicated in the "Victorian" forms of nervous and mental illness.

\section{I}

To be sure, individual medical writers long before Charcot had recognized a medical phenomenon in males which they believed paralleled female hysteria. During the long reign of the uterine theory, men appeared immune anatomically from the disorder. However, there emerged in the course of the seventeenth century a new model of mental illness centred on the nervous system, and, as part of this general development, the projected anatomical locus of hysteria shifted from the reproductive zone to the brain, the mind, or the nervous system as a whole. The idea of male hysteria now became a distinct theoretical possibility. It is common to credit the first clear expression of the idea of masculine hysteria to Charles Lepois, personal physician to Henry II of France: "Hysterica symptomata omnia fere viris cum mulieribus sunt communia-Hysterical symptoms are almost all common to both men and women", observed Lepois in $1618 .^{10}$ Later in the century, Thomas Willis and Thomas Sydenham in England argued innovatively that hysteria was a "nervous distemper" and that certain categories of men could fall prey to the affliction. Writing in 1681 in his Epistolary dissertation, Sydenham observed that,

Of all chronic diseases, hysteria-unless I err-is the commonest . ... As to females, if we except those who lead a hard and hardy life, there is rarely one who is wholly free from them [hysterical complaints] .... Then, again, such males as lead a sedentary or studious life, and grow pale over their books and papers, are similarly afflicted .... ${ }^{11}$

Given the etymology of the term, however, Willis and Sydenham anticipated that

\footnotetext{
${ }^{9}$ For the diffusion of Charcot's ideas through the European medical community, see Mark S. Micale, 'Diagnostic discriminations: Jean-Martin Charcot and the nineteenth-century idea of hysteria in the male', doctoral diss., Yale University, 1987, pp. 125-98. On child hysteria in the French-language medical literature, ibid., pp. 147-59.

${ }^{10}$ Cited in Veith, op. cit., note 1 above, p. 129.

${ }^{11}$ The works of Thomas Sydenham, 2 vols., translated from the Latin by R. G. Latham, London, Sydenham Society, 1848-50, vol. 2, p. 85. See also pp. 91, 94.
} 


\section{Charcot and the idea of hysteria in the male}

they would encounter strong scepticism in applying the hysteria label to men. Therefore, they introduced the notion that female hysteria found its male counterpart in hypochondriasis. ${ }^{12}$ It was chiefly through the hybrid hystero-hypochondriasis concept-a notion that among other things allowed doctors to acknowledge a similar pathology in both sexes while retaining a less pejorative designation for male patients - that the idea of masculine hysteria first entered medical history. ${ }^{13}$ Eighteenth-century French writing on the nervous disorders was caught up with the idea of "the vapours", which was applied to both sexes. In 1759, Joseph Raulin noted the occasional existence of convulsions accompanied by sensations of the globus hystericus in young men. ${ }^{14}$ And Pierre Pomme, in his popular Traite des affections vaporeuses des deux sexes, discussed at length a case of "hypochondriacal vapours" in a gentleman who had written to him in desperation for medical assistance. ${ }^{15}$

However, the initial statement of an idea in the intellectual history of medicine is not to be taken as synonymous with its widespread professional, much less popular, acceptance. Despite the appearance of the "neurological" theory of hysteria in the seventeenth century, the late eighteenth and early nineteenth centuries brought a full-scale revival of gynaecological theories of mental and nervous illness generally and hysteria in particular. ${ }^{16}$ This curious reversion to classical theory was endorsed by some of the outstanding medical figures of the time. In 1788, William Cullen proposed a special form of hysteria joined with nymphomania which he termed hysteria libidinosa, and Philippe Pinel, in the later editions of his Nosographie philosophique, classified hysteria among the "genital neuroses of women". ${ }^{17}$ By 1800 , the literal doctrine of the wandering womb had long been discredited; but the concept persisted in various anatomically and physiologically updated forms. Writing in 1816 , the French alienist J. B. Louyer-Villermay advanced the idea that the plexus of nerves emanating from the uterus through the entire body was the source of all nervous and mental maladies in women. ${ }^{18}$ Throughout his work, Louyer-Villermay defined hysteria synonymously as "uteromania" and "uterine epilepsy". In the opening pages of his book, and with references to Sydenham and Willis, he considered directly the question of "the supposed existence of the hysterical affection in individuals of the masculine sex". But, not surprisingly, he rejected the idea immediately. He conceded

\footnotetext{
12 See Thomas Willis, An essay of the pathology of the brain and nervous stock in which convulsive diseases are treated of, translated from the Latin by S. [amuel] P. [ordage] in Dr. Willis' practice of physick, London, Dring, Leigh, \& Harper, 1684, p. 69; and Sydenham, op. cit., note 11 above, vol. 2, p. 85.

${ }_{13}$ The best-known example of this equation was Bernard de Mandeville's A treatise of the hypochondriack and hysterical passions, vulgarly call'd hypochondria in men and vapours in women (1711).

14 Joseph Raulin, Traité des affections vaporeuses du sexe, Paris, J.-T. Herissant, 1758, Discours préliminaire, pp. xi and 13.

${ }^{15}$ Pierre Pomme, Traité des affections vaporeuses des deux sexes, Lyon, B. Duplain, 1765, ch. 16. To the best of my knowledge, this is the first extended case history of male hysteria in the medical literature.

${ }^{16}$ For an entertaining review of this subject, read Mark D. Altschule, 'Venus ascendant' in Altschule, Roots of modern psychiatry: essays in the history of psychiatry, 2nd rev. and enl. ed., New York, Grune \& Stratton, 1965, pp. 101-18.

17 William Cullen, 'Of hysteria or the hysteric disease' in First lines of the practice of physic, new ed., 4 vols., Edinburgh, C. Elliot, 1788, vol. 4, p. 98; Philippe Pinel, Nosographie philosophique, 3 vols., $3 \mathrm{rd} \mathrm{rev.}$ ed., Paris, J. A. Brasson, 1807, vol. 2, pp. 279-86.

18 J.-B. Louyer-Villermay, Traité des maladies nerveuses ou vapeurs et particulièrement de l'hystérie et de l'hypochondrie, 2 vols., Paris, J. B. Baillière, 1816, vol. 1, pp. 1-217.
} 
the occurrence of individual symptoms such as fits, sudden attacks of suffocation, and idiopathic paralyses in male patients. But, in a self-protective manoeuvre that was often repeated by male theoreticians in the history of the disorder, he argued that these morbid phenomena represented misdiagnosed cases of other diseases-rare types of epilepsy or satyriasis, a convulsive form of hypochondriasis, or tuberculosis in its early stages. ${ }^{19}$ "Man cannot be hysterical", Louyer-Villermay concluded bluntly. "He has no uterus." 20

The first half of the nineteenth century was marked by a prolonged and rather unconstructive debate over the precise anatomical seat of hysteria. Authors such as Georget, Voisin, Brachet, and Sandras argued for various versions of the neurophysiological view and, consequently, for the possibility of hysteria in the male. ${ }^{21} \mathrm{At}$ the same time, Dubois d'Amiens, Landouzy, Foville, and Romberg upheld, in different versions, the doctrine of Louyer-Villermay and argued that hysteria was limited to women between the ages of puberty and menopause. ${ }^{22}$ Throughout the period, genital models prevailed and received the official imprimatur of academic medicine. In 1840, Thomas Laycock, one of the foremost British physicians of his age, reflected the dominant view. A section of Laycock's general treatise on gynaecology was headed 'Hysteria is peculiar to Females'. "It is quite true", Laycock explained, "that cases have occurred occasionally in the male sex, presenting the phenomena of convulsive hysteria; but so rarely, and under such circumstances, that even if their exact similarity to the hysterical paroxysm of the female be admitted, like other exceptions, they but serve to prove the rule, namely, that it is the nervous system of the woman which is implicated in these affections." As if to convince himself one more time, he added that, "Indeed, the general fact is so universally acknowledged, and so constantly corroborated by daily observation, that anything in the shape of proof is unnecessary." 23

It was against this intellectual background that there appeared the most creative and comprehensive study of hysteria in nineteenth-century France, Pierre Briquet's Traité clinique et thérapeutique de l'hystérie of 1859 . Briquet, a physician at the

${ }^{19}$ Ibid., pp. 5-13.

20 Ibid., p. 116.

${ }^{21}$ Étienne Jean Georget, De la physiologie du système nerveux et spécialement du cerveau, 2 vols., Paris, J. B. Baillière, 1821, vol. 2, p. 239; Félix Voisin, Des causes morales et physiques des maladies mentales et de quelques autres affections nerveuses, Paris, J. B. Baillière, 1826, pp. 56-63; Jean Louis Brachet, Traité de l'hystérie, Lyon, J. B. Baillière, 1847, pp. 194, 207, 210, 211; Claude Sandras, Traité pratique des maladies nerveuses, 2 vols., Paris, J. B. Baillière, 1851, vol. 1, pp. 169-70. Trillat has pointed out that it was in Georget's writings of the 1820 s that sufferers of hysteria were first regularly referred to in plural masculine and neutral forms (i.e., "ils", "eux", "les malades") rather than in the feminine (Trillat, op. cit., note 1 above, p. 108).

${ }^{22}$ A. L. Foville, 'Hystérie' (1833) in Dictionnaire de médecine et de chirurgie pratiques, 15 vols., Paris, Gabon, 1829-36, vol. 10, pp. 275-95; Frédéric Dubois d'Amiens, Histoire philosophique de l'hypochondrie et de l'hystérie, Paris, J. B. Baillière, 1833, p. 452; Hector Landouzy, Traité complet de l'hystérie, Paris, J. B. Baillière, 1846, pp. 218-30; Moritz Romberg quoted in Henri Cesbron, Histoire critique de l'hystérie, Paris, Asselin \& Houzeau, 1909, pp. 193-4, 196.

${ }_{23}$ Thomas Laycock, A treatise on the nervous disorders of women, London, Longman, Orme, Brown, Green \& Longmans, 1840 , pp. 8, 9. See too the remark in a widely-used medical encyclopaedia of the 1840 s to the effect that a belief in hysteria in males was "une opinion qui compte aujourd'hui très peu de partisans": 'Hystérie' (1842) in Édouard Monneret and Louis Fleury (eds.), Compendium de médecine pratique, 8 vols., Paris, Béchet \& Jeune, 1836-46, vol. 5, p. 82. 


\section{Charcot and the idea of hysteria in the male}

Hôpital de la Charité in Paris, argued strenuously against his colleagues' return to reproductive theories of the disorder. Briquet had little doubt that hysteria was a disorder of the higher nervous system-"une névrose de l'encéphale"-and he insisted on its reality in both sexes. Briquet also understood clearly the sources of contemporary theoretical resistance to the idea of male hysteria: "It is entirely natural", he wrote at the outset of his treatise, "that doctors who regarded the uterus as the only site of hysteria have believed that this illness was the exclusive province of women, and that, from Hippocrates to our own time, the great majority of authors have continually claimed that men could not become hysterical ... It is easy to understand the importance that these writers place on the recognition of male hysteria. Considering the uterus as the sole origin of the disease, the existence of this neurosis in members of the masculine sex is the complete ruin of their theory."24 Briquet dismissed as false or fanciful most previous medical commentary on hysteria. He brought a new clinical and statistical richness to the study of the subject, buttressing his observations with 430 case histories gathered over ten years of his hospital practice. ${ }^{25}$ Among other innovations, Briquet boldly began his 700 -page study with seven fully documented case reports of adult male patients to which he assigned the diagnoses of "hystérie simple" or "hystérie complexe". 26

Briquet's was a substantial advance in the medical conceptualization of hysteria. However, the publication of his monograph did not see the abandonment of genital models of hysteria. Although meaningful for Charcot and the Salpêtrians of the 1880 s, as we will see, Briquet's book had comparatively little influence on his contemporaries. The decade after its publication, in fact, brought two events of greater influence on general European medical thinking. In 1861, the second edition of Wilhelm Griesinger's Die Pathologie und Therapie der psychischen Krankheiten appeared, with French and English translations in 1865 and 1867 respectively. Griesinger's book, probably the most influential psychiatric textbook of the century, included passing acknowledgement of male hysteria. But Griesinger chose to link the cases of the disorder in both sexes that he cited either to local urogenital diseases or to puberty, pregnancy, childbirth, and menstruation, both positions that ultimately proved inimical to a theory of the disorder in males. ${ }^{27} \mathrm{~A}$ second pertinent development was the emergence at mid-century of a specifically ovarian theory of hysteria. Inspired by advances within French and German medicine during the 1840s in the understanding of the physiology of ovulation, medical writers such as Piorry, Schutzenberger, Négrier, and Lee proposed that hysterical symptoms were caused by "irregularities" or "congestions" of the ovaries. ${ }^{28}$ Ovarian irritation, they contended,

\footnotetext{
24 Pierre Briquet, Traité clinique et thérapeutique de l'hystérie, Paris, J. B. Baillière, 1859, pp. 11, 12. In Charcot's personal copy of Briquet's book at the Bibliothèque Charcot, this passage is marked in the margin.

${ }^{25}$ For more information on Briquet and the recent scholarship about him, see Micale (1989), op. cit., note 4 above, pp. $242-4$.

${ }^{26}$ Briquet, op. cit., note 24 above, pp. 11-51.

27 Wilhelm Griesinger, Die Pathologie und Therapie der psychischen Krankheiten für Aerzte und Studierende, 2nd enl. and rev. ed., Stuttgart, Adolph Krabbe, 1860, pp. 184-6, 203-10. The reference to male hysteria appears on p. 186.

${ }^{28}$ P. A. Piorry, Traité de diagnostic et de séméiologie, 3 vols., Paris, Pourchet, 1840, vol. 2, pp. 564-79; Schutzenberger, 'Étude sur les maladies de l'ovaire', Gaz. Méd. Paris, 26 Sept. 1846, pp. 119-26; Robert
} 


\section{Mark S. Micale}

produced "pelvic neuralgias" which, through the reflex action of the nervous system, led to outbreaks of hysteria. Their work was well-received-Négrier's book was awarded the Prix Monthyon of the Paris Academy of Sciences in 1858-and it contributed to, among other things, the surgical fashion for ovariotomies during the 1860 s and 1870 s.

This, then, was the state of medical thinking in the early $1870 \mathrm{~s}$, when Charcot, at mid-point in his career, began to work on hysteria at the Salpêtrière hospital. The concept of masculine hysteria already possessed a lengthy history. But most of the observations on it had consisted of passing, programmatic statements with little theoretical elaboration, clinical illustration, or academic recognition. Despite the noteworthy achievements of late seventeenth-century English researchers and of Briquet's Traité, gynaecological explanations continued to predominate in Continental, British, and North American medical thought. The great majority of physicians, including many of the most "progressive" doctors of the day, held that hysteria, in some undefined but definite way, was, as it had always been, intimately caught up with the female generative system. The notion of the disorder in the male, or in children, played little or no part in their thinking or practice.

\section{II}

For all intents and purposes, Charcot "constructed" his theory of hysteria in its initial form over the six-year period from 1872 to 1878 . Throughout this period, the Salpêtrière, the large medical complex on the southeastern edge of Paris, admitted only female patients, as it had done since its inception over 200 years before. Charcot spent practically his entire career at the Salpêtrière, which supplied the primary repository of clinical material for his scientific theorization. It is important to understand that the original Charcotian model of hysteria was derived exclusively from the observation of female hysterical patients at an old, general, municipal hospital. ${ }^{29}$ Manuscript materials today at the Bibliothèque Charcot in Paris indicate that Charcot had begun to gather materials on the subject of masculine hysteria as early as 1878. The first instance of a male patient at the Clinique Charcot being diagnosed as hysterical appears in an informal hospital registry and is dated February, $1879 .{ }^{30}$ Charcot's first printed case history on the disorder, a two-part article on hysteria among adolescent boys, appeared in the periodical Le progrès

\footnotetext{
Lee, Clinical reports of ovarian and uterine diseases, London, John Churchill, 1853, report I; and Charles Négrier, Recueil de faits pour servir à l'histoire des ovaires et des affections hystériques de la femme, Angers, Cosnier \& Lachèse, 1858. A later (and quite eccentric) French expression of this theme may be found in Émile Chairou's Études cliniques sur l'hystérie—nature, lésions anatomiques, traitement, Paris, J. B. Baillière, 1870 , pp. 7-15, 30-40.

${ }^{29}$ The most important of Charcot's writings on female hysteria from this period are the seven lectures in the first volume of the Lefons sur les maladies du système nerveux (henceforth LMSN), recueillies et publiées par Bourneville (1872-78) in Oeuvres complètes de J. M. Charcot, 9 vols., Paris, Bureaux du Progrès Médical, Delahaye \& Lecrosnier, 1886-93, vol. 1 (1892), pp. 275-405 and 427-48. See also the three volumes of the Iconographie photographique, op. cit., note 2 above.

${ }^{30}$ Case of Pierre de Bassonnière, Archives de l'assistance publique. Salpêtrière, Registre de diagnostics, 6-R-90.
} 


\section{Charcot and the idea of hysteria in the male}

médical in December, $1882 .{ }^{31}$ His final publication on the subject, a case history involving a man who suffered from hysterical sleepwalking, appeared in January, 1893. ${ }^{32}$ We can state with precision, then, that Charcot's investigation of male hysteria spanned the 15-year period from 1878 to 1893 . With a longstanding and instinctive mistrust of medical philosophizing, Charcot never produced a general theoretical study of hysteria, in either its masculine or feminine versions. Rather, his writings took the form of compilations of individual case histories that were intended to communicate through lucid clinical illustration and to convince the reader through the sheer accumulation of empirical data. ${ }^{33}$ Medical historians traditionally employ case-historical materials to exemplify or individualize the theoretical writings of a given author. With Charcot, the task is necessarily reversed as we are required to reconstruct the general theory from a range of rich clinical narratives.

From my tabulations, Charcot published during his lifetime a total of 61 case histories of male patients with the primary diagnoses of hystérie, hystérie simple, grande hystérie, hystéro-épilepsie or hystéro-neurasthénie. His first series of writings on the subject, totalling 21 cases from 1882 to 1885 , appeared in the third volume of the Leçons sur les maladies du système nerveux. ${ }^{34}$ These clinical reports initially served as formal lectures, meticulously prepared, which Charcot delivered weekly in the medical amphitheatre of the hospital. Between 1887 and 1889, Charcot published another 28 cases of male hysteria in his well-known two-volume collection, the Legons du mardi à la Salpêtrière. ${ }^{35}$ In contrast to the formal lectures, these clinical lessons consisted of informal demonstrations, conducted either at a patient's bedside in the hospital ward or in Charcot's private examining office, which were recorded in student notebooks and later reconstructed and printed. During the early 1890 s,

\footnotetext{
31 'De l'hystérie chez les jeunes garçons', Prog. méd., 16-23 Dec. 1882, 10: (50-51): 985-7, 1003-4, reprinted in Leçons sur les maladies du système nerveux (henceforth $L M S N$, vol. 3), recueillies et publiées par M. M. Babinski, Bernard, Féré, Guinon, Marie and Gilles de la Tourette, in Oeuvres complètes, op. cit., note 29 above, vol. 3 (1890), lecture 6, pp. 79-96.

32 'Le somnambulisme hystérique spontané considéré au point de vue nosographique et médico-légal', Gaz. hebd. Méd. Chir., 7 Jan. 1893, 30(1): 2-7.

33 The clearest statements of Charcot's medical epistemology may be found in 'La médecine empirique et la médecine scientifique: parallèle entre les anciens et les modernes' (1867), reprinted in Maladies des vieillards; goutte et rhumatisme in Oeuvres complètes, op. cit., note 29 above, vol. 7 (1890), Introduction, pp. iii-xxxiii; and in the Legon d'ouverture to LMSN, vol. 3, pp. 1-22.

${ }^{34} L M S N$, vol. 3, lecture 6, pp. 89-91, 92-6; lecture 8, pp. 117-23; lecture 16, pp. 229-37; lecture 17, pp. 238-52; lecture 18, pp. 261-7, 267-71, 272-9; lecture 19, pp. 280-4, 283-4 n. 1, 284-9, 289-98; lecture 20, pp. 300-7; lecture 21, pp. 321-7, 327-34; lecture 22, pp. 344-69; lecture 23, pp. 370-85; lecture 24, pp. 394-8; lecture 25, pp. 399-421; lecture 26, pp. 422-38; Appendix I, pp. 441-59, 459-62; and Appendix V, pp. 483-512. Note that it was this volume of Charcot's writings, in which almost all the cases of hysteria occur in male patients, that the young Sigmund Freud translated into German in 1886.

${ }^{35}$ Leçons du mardi à la Salpêtrière. Professor Charcot. Policliniques. 1887-1888. Notes de cours de MM. Blin, Charcot, Colin (henceforth, Leçons du mardi, vol. 1), Paris, Bureaux du Progrès Mèdical, Delahaye \& Lecrosnier, 1887 [sic], lesson 4, pp. 60-2, 62-5; lesson 11, pp. 199-209, 209-13; lesson 12, pp. 227-9; lesson 16, pp. 288-300, 305-9; lesson 18, pp. 338-43, 344-7, 348-53; lesson 19, pp. 357-63, 367-8; lesson 20, pp. 378-84, 386-7, 387-8; Leçons du mardi à la Salpêtrière. Professor Charcot. Policlinique. 1888-1889. Notes de cours de MM. Blin, Charcot, Colin (henceforth, Leçons du mardi, vol. 2), Paris, Bureaux du Progrès Médical, Lecrosnier \& Babé, 1889, lesson 2, pp. 19-37; lesson 3, pp. 43-53; lesson 5, pp. 83-100; lesson 6, pp. 121-5; lesson 7, pp. 131-9; lesson 9, pp. 189-98; lesson 12, pp. 261-5, 265-9; lesson 13, pp. 285-92, 292-9; lesson 15, pp. 347-53; lesson 17, pp. 393-9, 399-403; lesson 18, pp. 419-33; lesson 19, pp. 436-62; lesson 21, pp. 502-9, 518-23; Appendix I, pp. 528-35; Appendix III, pp. 543-8.
} 
Charcot included several more statements in the two volumes of his Clinique des maladies du système nerveux; ${ }^{36}$ and at least four further cases, not reproduced in the Oeuvres complètes, were published in contemporary medical periodicals. ${ }^{37}$ In addition to these printed sources, the Bibliothèque Charcot at the Salpêtrière contains extensive manuscript materials, many in Charcot's own handwriting, on another 18 cases. Libraries outside France also hold a number of relevant documents. ${ }^{38}$ Finally, the Archives de l'Assistance Publique in Paris houses a fragmentary diagnostic registry that includes biographical and clinical data on 11 hysterical patients-four women and seven men-who were treated at the outpatient clinic of the Salpêtrière between 1879 and $1883 .{ }^{39}$ All in all, then, information exists on over 90 male patients whom Charcot regarded as hysterics. This sizeable literature establishes at once that for Charcot, "hystérie mâle" was not merely a theoretical possibility, a clinical rarity, or a textbook abstraction, but a workaday diagnosis.

Within the Salpêtrière, Charcot's male patients came from two places, the recently established out-patient clinic, or consultation externe, and the General Infirmary of the hospital. Since the seventeenth century, the Salpêtrière had served as an enormous welfare establishment for poor, sick or dispossessed women while their male counterparts were transported farther ouside the city to the Bicêtre hospital. However, in 1882, and specifically at the behest of Charcot, a special ward was established on the site of the General Infirmary for male patients. This new Service des hommes, located along the Rue de l'Infirmerie in the Deuxième Section of the hospital, was devoted to the study and treatment of subjects suffering from transient nervous and neurological disorders. The new wing initially contained twenty beds; two years later, this was expanded to fifty. ${ }^{40}$ Also in 1885 the general wards of the

\footnotetext{
${ }^{36}$ Clinique des maladies du système nerveux. M. le Professeur Charcot. Leçons du Professeur, Mémoires, Notes et Observations, 1889-1890 et 1890-1891, publiés sous la direction de Georges Guinon, 2 vols., Paris, Bureaux du Progrès Médical, Babé \& Cie, 1892-3, vol. 1, lecture 2, pp. 30-45; lecture 3, pp. 53-61, 61-4, 64-9; lecture 5, pp. 95-116; lecture 14, pp. 292-307; vol. 2, Appendix II, pp. 461-72, 472-4.

37 'Spasme glosso-labié unilatéral des hystériques. Diagnostic entre l'hémiplégie capsulaire et l'hémiplégie hystérique', Sem. méd., 1887, 7: 37-8; 'Des paralysies hystéro-traumatiques chez l'homme', ibid., pp. 490-1; 'Sur un cas de monoplégie brachiale chez l'homme, présentant des difficultés de diagnostic', ibid., 1892, 12: 225-7; 'Le somnambulisme hystérique', op. cit., note 32 above.

38 Case of "Guénin”, Countway Medical Library, Boston, Rare Book Room, Manuscripts Collection. Charcot. Folio C96; Wellcome Institute for the History of Medicine, London, Manuscripts Collection. Charcot.

${ }^{39}$ Archives de l'assistance publique. Salpêtrière, Registre de diagnostics, 6-R-90.

40 G. Daumezon, 'Essai historique et critique de l'appareil d'assistance aux malades mentales dans le département de la Seine depuis le début du XIXè siècle', L'Inf. psychiat., Jan. 1960, 1: 26; and 'Hospice de la Vieillesse: Plan Général' in Ludwig Hirt, Das Hospiz 'La Salpêtrière' in Paris und die Charcot 'sche Klinik für Nervenkrankheiten, Breslau, Grass-Barth, 1883, with annotations by Charcot. Unfortunately, I have been unable to locate hospital records for the Service des hommes during the years immediately following its opening. However, other sources offer valuable statistical information: Gilles de la Tourette recorded that, between 1882 and 1889 , a total of 872 men were treated at the new facility and that 77 of these were considered hysterical (Gilles de la Tourette, Traité clinique et thérapeutique de l'hystérie d'après l'enseignement de la Salpêtrière, 3 vols., Paris, Plon, Nourrit, \& Cie, 1891, vol. 1, p. 64). Georges Guinon, Charcot's chef de clinique for several years, stated further that in 1889 the Service Charcot and the out-patient clinic between them administered to 109 hysterical patients, of whom 79 were women and 30 men (Guinon, 'La policlinique de M. le Dr. Charcot à la Salpêtrière' in Clinique des maladies, op. cit., note 36 above, vol. 2, pp. 430-9). And an annual report from the Department of Ophthalmology for 1888 reveals that 79 hysterical patients received eye examinations that year -49 women and 30 men: Dr Morax,
} 


\section{Charcot and the idea of hysteria in the male}

Service Charcot at the Clinique des Maladies du Système Nerveux began to accept male patients, who usually suffered from more chronic disabilities and resided at the hospital for longer periods of time. The important point is that, by the first half of the 1880 s, the requisite patient pool for a close and systematic study of hysterical disorders in males was available for Charcot, and it is surely no coincidence that his first pronouncements on the subject emerged at this time. ${ }^{41}$ The acceptance of the first men at this institution for women parallels neatly Charcot's masculinization of the old "feminine" diagnosis of hysteria.

Why, then, after a decade and a half of work in traditional internal, geriatric, and neurological medicine did Charcot embrace such a controversial subject as masculine hysteria? Charcot's motivations, I believe, were personal, professional, scientific, and cultural. After many years of clinical experience, Charcot had genuinely come to believe that men and children were susceptible to the same functional nervous disorders as women. And his personal observations were reinforced by two earlier texts. Since his days as a young physician rotating through the hospitals of Paris, he had been inspired by the accuracy, common sense, and clinical acumen of Briquet's treatise, with its strong opening endorsement of male hysteria. He had also been impressed by a more obscure but recent source, a short but highly original medical dissertation entitled De l'hystérie chez l'homme, written by one Auguste Klein in $1880 .^{42}$ This was a collation, in both literary and tabular forms, of 78 cases of nervous disorders, drawn widely from the medical literature of the preceding two centuries, which Klein maintained were misdiagnosed instances of hysteria in men. Complimentary references to Briquet's treatise occur often in Charcot's writings on male hysteria, and his detailed handwritten notes on Klein's thesis remain among the papers at the Bibliothèque Charcot.

Charcot's concern with the hysteria diagnosis in men should also be seen as a logical extension of his earlier general work on the disorder. By the end of the 1870s, Charcot had completed his theory of female hysteria. His writings had received widespread professional recognition, and scientific research on the subject was associated above all with his name. During the final 15 years of his career, Charcot modified the basic structure of this theory very little. However, what he did do throughout this period was to apply it to an ever wider range of medical populations. Furthermore, his work on hysteria in the 1880s was characterized by a kind of nosographical inflation, whereby the scope of clinical phenomena ascribed to the disorder expanded continually. ${ }^{43}$ Charcot's completion of the proto-theory of female hysteria and his first interest in hysteria in men and children both occurred between

\footnotetext{
'Hospice de la Salpêtrière. Clinique des maladies du système nerveux-Compte rendu du service ophthalmologique', Archs Neurol., May 1889, 17(51): 437, 443-6.

${ }^{41}$ On the various interconnections of Charcot's medical theories and the institutional circumstances of the Salpêtrière, see Mark S. Micale, 'The Salpêtrière in the age of Charcot: an institutional perspective on medical history in the late nineteenth century', J. contemp. Hist., 1985, 20: 703-31.

42 Auguste Klein, De l'hystérie chez l'homme, doctoral diss., Paris Medical Faculty, 1880. Klein was a medical student at the Hôpital Necker.

${ }^{43}$ Among contemporary observers, Pierre Janet recognized the importance of this process for understanding Charcot's work. See Janet, 'Quelques définitions récentes de l'hystérie', Archs Neurol., July 1893, 26(77): 17-18.
} 


\section{Mark S. Micale}

1878 and 1880. The coincidence suggests that adult and adolescent males offered to Charcot a new, large, and previously untapped clinical population to which he could apply his favourite nosographical creation.

To these factors should be added the role of what we might call the cultural ideology of the School of the Salpêtrière. The medical world of late nineteenthcentury France was large and diverse and within it Charcot and his students formed a kind of medical avant-garde. They saw themselves as a cadre of latter-day medical philosophes determined to rout out vestiges of past error and ignorance wherever these persisted. ${ }^{44}$ Ostentatiously replacing the beliefs of earlier, "pre-scientific" times with the methods and findings of modern empirical science was an intellectual gesture that Charcot found enormously gratifying and one he repeated as often as possible. From this perspective, the theme of hysteria proved irresistible. For centuries, the neurosis had been entangled with scientific myths, popular prejudices, and religious persecutions. The theme of male hysteria in particular appealed. Echoing Briquet, Charcot believed that it could only have been through centuries of error and ignorance that the uterine theory had prevailed and the simple reality of hysteria in the male gone unrecognized. In this he was not alone. The many monographs on male hysteria coming out of France at this time typically begin with an Apercu historique, which in fact served as mild scientific propaganda, chronicling the advance of the contemporary scientific understanding of hysterical illness over the crude beliefs and inhumane practices of the past. ${ }^{45} \mathrm{~A}$ detailed, dispassionate, and technically sophisticated discussion of adult male hysteria, then, was for Charcot a classic manoeuvre in the French rationalist tradition.

Charcot's campaign on behalf of male hysteria also reveals a clear intraprofessional agenda. As Étienne Trillat has astutely observed, the intellectual history of hysteria since the mid-nineteenth century has been divided decisively along intraprofessional lines, with each group of specialists advocating the model of the disease that enhanced its explanatory authority over the subject. ${ }^{46}$ In Charcot's time, the major competitors in this regard were gynaecologists, obstetricians, internists, alienists, and neurologists. In these disputes Charcot, in the last camp, was an eager and aggressive player. $\mathrm{He}$ formed a school of students, founded professional journals, established a new clinical facility at the hospital, and lobbied for the funding of a new academic chair-all toward the advancement of the neurological study of the maladies nerveuses. Integral to Charcot's efforts in this direction was his model of hysteria, with a neuropathic theory of aetiology, a symptomatology that emphasized paralyses, anaesthesias, and contractures (rather than mental states), and a highly physicalistic regimen of therapy. In the theoretical competition among specialists, the idea of hysteria in the male proved highly serviceable. Since Willis and Sydenham, medical arguments for the recognition of masculine hysteria had been coupled with explicit rejections of

\footnotetext{
44 On the self-image of the Salpêtrians, consult Charles Richet, "Aux temps heroïques de la médecine, 1872-1878', Prog. méd., 16 Dec. 1922, 50: 589.

45 See the introductory historical remarks in Léon de Casaubon, L'hystérie chez les jeunes garçons, doctoral diss., Paris Medical Faculty, 1884; Émile Batault, Contribution à l'étude de l'hystérie chez l'homme, doctoral diss., Paris Medical Faculty, 1885; and Paul Michaut, Contribution à l'étude des manifestations de l'hystérie chez l'homme, doctoral diss., Paris Medical Faculty, 1890.

46 Trillat, op. cit., note 1 above, pp. 121-5.
} 


\section{Charcot and the idea of hysteria in the male}

gynaecological models of the disorder. Charcot understood the potential of this strategy well. In his first published writings on the subject from the early 1880 s, he routinely cited the existence of cases of hysteria in adult men (and, incidentally, in prepubertal children and post-menopausal women) as conclusive disproof of the genital theories that had been revived earlier in the century. In the decade following his death, Charcot's efforts to bring the scientific study of hysterical disorders firmly into the domain of neurological medicine were defeated with the rise of privatepractice psychiatry; but, during the 1870 s and the 1880 s, Charcot's neurological model of hysteria became established throughout the mainstream European and North American medical world, and he ended permanently the claims of gynaecologists and obstetricians to authority over the subject.

Finally, and related to this last point, Charcot's pursuit of the theme of male hysteria was motivated by a specialized humanitarian concern. The final third of the nineteenth century in Germany, Britain, and the United States witnessed the widespread practice of amputative gynaecological surgery in the treatment of women with nervous disorders. As Lawrence Longo has demonstrated, these radical interventions, which included hysterectomies, clitoridectomies, and unilateral and bilateral ovariotomies, reached their greatest frequency between 1875 and $1885 .{ }^{47}$ Not surprisingly, gynaecologists and gynaecological surgeons were the foremost advocates of the procedures. These practices were never as common in France as in other countries; but a number of prominent Parisian physicians, most notably Péan and Richelot, wrote enthusiastically in favour. As we shall see, Charcot was not beyond practising physical manipulations of the genitalia in his treatment of hysterical patients. But, throughout his career, he remained unalterably opposed to these surgical activities, which he believed were as ineffective as they were sadistic. Charcot argued often and outspokenly against these treatments, and a number of times he chose to do so in his writings on male hysteria. ${ }^{48} \mathrm{I}$ suspect this was not a coincidence. By propounding a theory of hysteria in the male, Charcot was also attempting to undermine the theoretical model of the disorder which had led to some of the most deplorable therapeutic activities of his day. Charcot's interest in the subject of male hysteria was nothing if not overdetermined.

\section{III}

It will be apparent that Charcot's work on hysteria in adult men, from beginning to end, was highly controversial. Throughout the 15 years of his writing on the subject, Charcot cultivated this controversy, although exactly what he was arguing for and against changed over time. Early on, he was concerned simply to establish the reality and frequency of hysterical illnesses in the male sex, by defining his theory in opposition to earlier models of the disease. "In truth", he wrote in 1888, "words, and particularly words in medical nosography, mean nothing except as symbols. They

\footnotetext{
${ }^{47}$ Lawrence D. Longo, 'The rise and fall of Battey's operation: a fashion in surgery', Bull. Hist. Med., 1979, 53: $244-67$.

48 See, for instance, $L M S N$, vol. 3, lecture 23, pp. 372-3 and Leçons du mardi, vol. 1, lesson 4, pp. 63-4. The strongest statement of the surgical conservatism of the School of the Salpêtrière is Gilles de la Tourette, 'Du traitement chirurgical de l'hystérie', Archs Tocol. Gynéc., 20 June 1895, 22: 409-20.
} 


\section{Mark S. Micale}

cannot claim to possess the merit of a descriptive definition. Get yourself into the habit of thinking ... that in itself the word hysteria signifies nothing, and little by little, you will get used to speaking of hysteria in men without thinking in the least of 'the uterus'." 49 What was required, Charcot believed, was a break with the history and etymology of the disease. He sought a modernization of the concept based on a reliable empirical methodology that would "make you recognize and, so to speak, see for yourself the identity of the great neurosis in the two sexes". ${ }^{50}$ As Griesinger had shown 20 years earlier, a genital model of the disease was not incompatible with a belief in male hysteria; but the two ideas had more often than not proven mutually hostile. Consequently, a strong anti-Hippocratic impulse runs through Charcot's writings from the first half of the 1880s. In 1889, after his ideas had been accepted, Charcot reflected on whether male hysteria was, after all, so much less common than the disorder in the female. "Whatever answer will be given to this question in the future," he concluded with satisfaction, "we are presently very far from the idea of our predecessors of past centuries who made of hysteria . . . only 'a suffocation of the uterus'."51

In his attempt to "modernize" the male hysteria diagnosis, Charcot anticipated, and argued against, a number of what he believed were old and destructive stereotypes. Specifically, he rejected from the outset the notions that the disorder was limited to boys at the age of puberty; that it existed solely in the leisured upper classes of society; and that it occurred exclusively in effeminate or homosexual men. On the question of age, Charcot maintained that hysterical disorders could develop at any period of life, from infancy to old age. Among his published cases of males, the youngest is 11 years of age, the oldest $56 .{ }^{52} \mathrm{He}$ found the greatest concentration of cases in people between the ages of 20 and 40 . Charcot was also concerned that the disorder should not be dismissed as the manifestation of a transient adolescent crisis, and he therefore often underscored the fact that a given patient was "in the vigour of age [and] full maturity". ${ }^{53}$ Briquet had estimated the ratio of the occurrence of the disease between men and women to be 1:20. Charcot believed that, in each age bracket, the ratio was slightly closer than this. ${ }^{54}$

${ }^{49}$ Leçons du mardi, vol. 2, lesson 2, (30 Oct. 1888), p. 37.

50 'A propos de six cas d'hystérie chez l'homme (1)', $L M S N$, vol. 3, lecture 18, p. 253.

${ }^{51}$ Leçons du mardi, vol. 2, lesson 17, (12 March 1889), p. 393.

52 These are the cases of the Breton boy, "François X.", found in $L M S N$, vol. 3, lectures 16 and 17, pp. 229-37 and the factory worker "P...on" in Leģons du mardi, vol. 2, lesson 3, pp. 43-53.

${ }_{53} \mathrm{Op}$. cit., note 50 above, p. 253.

54 Briquet, op. cit., note 24 above, p. 36 and Charcot, $L M S N$, vol. 3, lecture 8, p. 114. The exact statistical relationship of male to female hysteria was a matter of much debate among doctors at the time, with many physicians projecting a significantly higher rate among men than Charcot. From a large four-year study conducted at the general hospital of Würzburg in the mid-1880s, for instance, Professors Mendel and Eulenberg found the incidence of the disorder between the sexes to be 1:10 (cited in O. Bodenstein, Hysterie beim männlichen Geschlecht, doctoral diss., Würzburg Medical Faculty, 1889, p. 18). Albert Pitres, Dean of the Bordeaux Medical School, reported that of 100 arbitrarily chosen hysterical patients from his practice, 31 turned out to be males (cited in Émile Bitôt, L'Hystérie mâle, doctoral diss., Bordeaux Medical Faculty, 1890, p. 136), In 1891, Gilles de la Tourette, reflecting on his earlier experience at the out-patient clinic of the Salpêtrière, stated that "il nous a semblé qu'on observait un hystérique homme pour deux ou trois femmes atteintes de la même affection" (Traité clinique, op. cit., note 40 above, vol. 1, p. 66). A number of years earlier, Dr Natier, a prominent Parisian rhinolaryngologist, had surveyed hysterical disorders of language among his patients and found that they divided equally between the sexes: 'Contribution à l'étude 


\title{
Charcot and the idea of hysteria in the male
}

Concerning the social epidemiology of male hysteria, Charcot rejected the received wisdom. From Rabelais to Robert Burton to Benjamin Rush, medical men had observed the greatest susceptibility to minor mental illnesses in members of the affluent classes and had blamed this on an idle, self-indulgent style of living. The seventeenth-century English literature on hypochondriacal melancholia, for instance, and eighteenth-century commentary on the vapours dealt almost exclusively with individuals from the upper- and upper-middle classes. Similarly, a number of major nineteenth-century psychiatric and neurological textbooks recorded a much higher incidence of hysteria, hypochondria, and general nervousness in the middle and upper classes of society. At mid-century, the perception of widespread nervous disorders among the lower social orders began selectively to enter European medical discourse. But the old social and medical associations were reinforced during the next generation. In America, George M. Beard chose to reserve the new and fashionable diagnosis of neurasthenia for the "brain workers" of the modern business world, while Silas Weir Mitchell, whose writings, like Beard's, were translated into French in the 1880s, coaxed and coddled some of the most affluent women of Anglo-American society. In France and Britain, the image circulated through the writings of such fin-de-siècle literary figures as Huysmans, Wilde, and, later, Proust, in which the character of the effete aristocrat, morbidly preoccupied with the cultivation of his nervous eccentricities, figured prominently. Charcot knew this picture well, in both its medical and literary versions, and reacted sharply against it:

\begin{abstract}
When we speak today of neurasthenia or male hysteria, it still seems that we almost exclusively have in mind the man of the privileged classes, sated by culture, exhausted by pleasures' abuses, by business preoccupations, or an excess of intellectual exertion. This is an error that I have many times had to argue against and against which it will no doubt be necessary to argue for a long time to come, because it appears far from being eradicated. However, it has been perfectly well-established that these same disorders, at least in the cities, may be observed on a grand scale among the workers and artisans, by those the least favoured by fate and who scarcely know anything other than hard manual labour.
\end{abstract}

In the face of disease, Charcot went on, men of all classes are created equal:

We must not forget that the psychological constitution [of working-class people] is fundamentally the same as ours, and that, perhaps even more than other people, they are subjected to the destructive effects of painful moral emotions, of anxieties related to the material difficulties of life, to the depressing influence of the exaggerated effect of physical forces .... In addition, we should remember that neuropathic heredity is scarcely the exclusive privilege of the wealthy in life. It extends its reach to the working class as to everywhere else. ${ }^{55}$

Accordingly, the most immediately striking feature of Charcot's male hysterical patients concerns their socio-economic identity. Of the $61 \mathrm{men}$ and boys in his

du mutisme hystérique', Rev. Laryngoscopie, 1888, 4: 16-29. And Alexander Souques maintained that at the Hôpital Broussais certain forms of the disease occurred twice as commonly in males as females: 'De l'hystérie mâle dans un service hospitalier', Archs gén. Méd., Aug. 1890, 26: 172-4.

55 Charcot, Leçons du mardi, vol. 2, lesson 12, (29 Jan. 1889), p. 256. Later in the lesson Charcot adds that "il est remarquable que chez les sujets rustiques des classes ouvrières, les affections nerveuses sans 


\section{Mark S. Micale}

published writings, all but five had urban or agricultural working-class backgrounds. Two of the five, both teenagers, came from wealthy families while the other three were beggars or vagabonds. ${ }^{56}$ The great majority of the hysterical men in Charcot's published writings were masons, bakers, carpenters, gardeners, plumbers, locksmiths, railway workers, factory workers, and so on. They were, that is, either labourers in new, large-scale, mechanized industries or, more often, members of the traditional artisanal crafts or petits métiers of Paris. ${ }^{57}$ Furthermore, nearly all of the male patients sent by other physicians from outside the Salpêtrière for consultation with Charcot came from hospitals in working-class districts of Paris, such as the Hôpital Saint-Louis near Belleville. Gilles de la Tourette once indicated that some of the highest levels of male hysteria in the French capital were found in the artisanal Faubourg Saint-Antoine, ${ }^{58}$ and Pierre Marie, in a controversial study, contended that hysterical disorders in men from "les classes dites inférieures" were statistically much more common than in women. ${ }^{59}$ In addition, as Michèle Ouerd has perceived, it was specifically the inability of these male patients to work due to their nervous disabilities that defined their sickness in the eyes of middle-class physicians and led to their diagnosis and hospitalization. ${ }^{60}$

The social constitution of Charcot's patient population is a complex matter, the result of a number of factors. First, Charcot, by way of official explanation, maintained that the increased vulnerability of working men to nervous illnesses was due to the greater physical exertions and emotional strains to which they were subjected and to noxious environmental influences in the workplace. These factors may well have been important. Second, we should recall that the Salpetrière remained at this time a free municipal hospital, drawing nearly its entire population from the lower social echelons. Moreover, the hospital was located in the centre of a large working-class neighbourhood, in the northeastern section of the 13th arrondissement. When people in the area fell ill, they naturally sought assistance at the nearest public medical facility. Nevertheless, it is difficult not to think that the sociological composition of Charcot's patients reflected more than the circumstances under which the doctor and his patients worked. During the second half of the nineteenth century, as material conditions improved at municipal urban hospitals, an increasing number of bourgeois patients sought medical care at institutions such as the Salpêtrière. Moreover, while Charcot throughout this period spent his mornings at the hospital, he devoted afternoons to a thriving private practice at his residency in SaintGermain-des-Prés. Here he saw every day a very different and socially diversified

\footnotetext{
'substratum' organique-la neurasthénie, l'hystérie, par exemple-se montrent généralement, toutes choses égales d'ailleurs, plus graves et plus tenaces que chez les sujets plus délicats, plus impressionnables des classes lettrées" (p. 261).

${ }^{56}$ The cases of the two upper-middle-class individuals are located in $L M S N$, vol. 3, lecture 6, pp. 92-6 and Leçons du mardi, vol. 1, lesson 11, pp. 199-209.

57 Charcot once referred to male hysteria in its traumatic form as "l'hystérie du maçon, du serrurier": 'Des paralysies', op. cit., note 37 above, p. 490.

58 Gilles de la Tourette, op. cit., note 40 above, vol. 1, p. 112.

59 Pierre Marie, 'L'hystérie à la consultation du Bureau central des hôpitaux de Paris: Étude statistique', Prog. méd., 27 July 1889, 10(30): 68-70.

8 Legons sur l'hystérie virile, op. cit., note 8 above, Introduction, p. 21.
} 


\section{Charcot and the idea of hysteria in the male}

clientele. And yet, examples of the disorder in the middle or upper-middle classes are strikingly absent from Charcot's printed case histories of male hysterics. It is likely that to some degree Charcot and his followers were able to bring the diagnosis of hysteria to members of their own sex because in other ways (i.e., socially) the individuals involved remained distanced from them.

On numerous occasions, Charcot did locate a hysterical symptomatology in males from outside the working classes, at both ends of the social spectrum. But, upon close examination, the exceptions prove the rule. In private practice, Charcot regularly saw male patients from the comfortable classes suffering from nervous ailments, patients similar to those written about by Beard, Mitchell, Playfair, and Freud. However, it is revealing that, unlike these contemporaries, Charcot never printed any of the cases from his private practice. ${ }^{61}$ Moreover, while records from Charcot's private practice are rare today, the evidence suggests that private male patients with hysteria-like symptoms were more likely to be absorbed into the neighbouring diagnostic category of neurasthenia - a diagnosis that was just entering French medicine in the early 1880s and that offered a respectable aetiology and a hopeful prognosis-than to be burdened with the dire and disreputable label of hysteria. ${ }^{62}$

Conversely, Charcot on a small number of occasions published cases of male hysteria in members of the lowliest and most impoverished social classes. ${ }^{63}$ "Where does hysteria hide?", Charcot asked during one of his clinical lessons in 1889. "In the last few years, I have often shown [that it hides] in the working class and among manual artisans. We must also search for it in the gutter, among the beggars, the vagabonds, and the dispossessed, in the poor houses and even perhaps the jails and penitentiaries." ${ }^{\prime 64}$ However, with two of the three cases in this social category, Charcot added the still more denigratory diagnosis of degeneration to the label of hysteria. This combined diagnosis is rare in Charcot's work and, from my reading, not merited by the clinical content of these cases. The complex interactions between diagnostic theory and social class in nineteenth-century medicine remain an important subject for future investigation. ${ }^{65}$ Unfortunately, the extant documentation concerning Charcot's medical practice is insufficient to permit definite conclusions. However, a clear class-specific pattern does begin to emerge in Charcot's diagnostic handling of his male patients. This pattern of labelling involves neurasthenia or hystero-neurasthenia for private upper-class patients; hysteria proper for working-class men; and hysteria and degeneration for the indigent.

This social schema fails to conform to the various expectations we might bring to

${ }^{61}$ Extensive clinical notes exist at the Bibliothèque Charcot for the patient Albert Rose, a well-educated 34-year-old Frenchman who worked in Paris as a botanist and horticulturalist and who was diagnosed with "hystero-traumatism" in the spring of 1883. Rose's case was never published.

62 Relevant in this regard are the case notes, recorded on Charcot's private stationery, for a certain Monsieur Defly. Defly, who resided in the fashionable Parisian neighbourhood of Clichy, received the diagnoses of "Neurasthénie, anémie, dyspepsie consécutive" (Wellcome Institute Library, Autograph Manuscript Collection. Charcot, document dated 4 November 1887).

${ }^{63}$ These are the cases of the beggar Klein (Lefons du mardi, vol. 2 lesson 15, pp. 347-53), the circus saltimbanque "Lap...sonne" (ibid., lesson 17, pp. 393-9), and the streetsinger "Ro...eau" (ibid., pp. 399-403).

64 Ibid., p. 393.

${ }^{65}$ Micale (1990), op. cit., note 4 above, pp. 84-93. 


\section{Mark S. Micale}

the subject. By and large, Charcot's male hysterics were not the repressed bourgeois neurotics of early psychoanalysis; nor were they the nervous and debauched aristocrats of contemporary cultural folklore; nor the socially uncontrollable marginaux that, in the historical picture provided by Michel Foucault, populated Parisian hospitals during the ancien régime. Rather, Charcot seems to have reserved the diagnosis of hysteria for a quite specialized socio-economic category, between the worlds of the bourgeois and the bohemian. For the most important theorist of the disease in the last century, male hysteria by and large was a disorder of working men - of the labouring but non-dangerous classes, we might call them-who had led steady, hard-working lives before their illnesses forced them to drop out of the capitalist order. ${ }^{66}$

Finally, in writing about "hystérie virile", Charcot seized every opportunity to establish the authentically masculine nature of the disorder. The lingering suspicion he was addressing in this regard was widespread. To cite only two examples, in 1845 the Viennese alienist Ernst von Feuchtersleben had commented in his textbook of psychiatry that "When men are attacked by genuine hysterical fits (globus hystericus, etc.), which certainly does occur, they are, for the most part, effeminate men." ${ }^{\prime 67}$ And, 20 years later, John Russell Reynolds wrote in his System of medicine that hysterical disorders were extremely rare in members of his own sex. "When hysteria is found in either a man or a boy, it is to be observed that such person is, either mentally or morally, of feminine constitution." 68

On this point, too, Charcot argued against the grain. "These adult men who are prey to the hysterical neurosis", he insisted, "do not always present characteristics of femininity. Far from it. They are, at least in a majority of cases, robust men presenting all the attributes of the male sex, soldiers or artisans, married and the fathers of families, men, in other words, in whom one would be surprised, unless forewarned, to meet with an illness considered by most people as exclusive to women." ${ }^{\prime 29}$ At the beginning of a set of lectures in 1885 presenting six cases of male hysteria, Charcot elaborated on the point:

We concede that an effeminate young man, after certain excesses, disappointments, deep emotions, may present various phenomena of a hysterical nature; but that a vigorous and well-built artisan, not enervated by high culture, a train engineer for example, not previously overly-emotional, or at least not in appearance, may... become hysterical, just like a woman ... now there, it seems, is something that has never entered the imagination of some people. Nothing, however, is better proven,

\footnotetext{
${ }^{66} \mathrm{My}$ reading of the social identity of Charcot's male hysterical patients diverges from that of Ouerd (Introduction to Lecons sur l'hystérie virile, op. cit., note 8 above, pp. 26-8) and Jan Goldstein ('The wandering Jew and the problem of psychiatric anti-semitism in fin-de-siècle France', J. contemp. Hist., 1985, 20: 538-45. Following a Foucauldian line of analysis, Ouerd and Goldstein have emphasized those male patients of Charcot's who came from the most marginal and politically disempowered sectors of society. But the matter seems to me to be settled statistically. The begging and itinerant poor constitute only three out of the 61 patients in Charcot's overall case-load of hysterical males (see note 63 above), or 4.9 per cent of the total, and to impose on them an interpretive centrality is misleading.

${ }^{67}$ Ernst von Feuchtersleben, The principles of medical psychology, translated from the German by H. E. Lloyd, rev. and ed. B. G. Babington, London, Sydenham Society, 1847, p. 228.

68 J. Russell Reynolds, 'Hysteria' in Reynolds (ed.), A system of medicine, 5 vols., London, Macmillan, 1866-79, vol. 2, p. 307.

69 'Deux cas de contracture hystérique d'origine traumatique (2)', $L M S N$, vol. 3, lecture 8, p. 115.
} 
and it is a notion we must get used to. This will happen in time, just as so many other propositions are established today as demonstrated truths in everyone's mind after having aroused scepticism and often irony for a long time. ${ }^{70}$

In keeping with these views, Charcot was determined to establish the solid sexual credentials of the patients under his care. His case histories frequently began with amusing remarks on the sturdy physical traits of the patient: with a case of "hysterical contracture" in an unnamed 34-year-old blacksmith, Charcot described the man as "the father of four children, quite robust, and without any sign of effeminacy" ${ }^{71} \mathrm{He}$ introduced Antoine Charnu, a 41-year-old baker who came to the hospital in March of 1892, as "a rigorously built patient, musculature very developed" with "a very calm character". ${ }^{72}$ And fragmentary notes remain for the case of one Jean-Pierre Mattivet. Charcot carefully characterized Mattivet, who was plagued by a number of severe hysterical symptoms, as "a robust labourer" and pointed out that the patient had manfully undergone amputation of an arm during the Franco-Prussian War. ${ }^{73}$ Other manuscript materials from the Charcot Library considerably qualify this picture; there are many observations of effeminacy in male hysterical patients in his personal clinical notes. ${ }^{74}$ However, in his official model of male hysteria as formulated in the published case histories, Charcot never referred to habits, mannerisms, or activities that could conceivably have compromised a patient on this score.

Not surprisingly, Charcot never broached the subject of homosexuality in any of his writings on male hysteria. Here, too, I suspect, he did not want his prize diagnostic category reduced by his professional enemies to a narrow clinical caricature, or discarded through contemporary medical predudice. In the Archives de neurologie of 1882, Charcot did publish a lengthy and quite frank account of a homosexual man, "Monsieur X.", a university professor from the provinces. ${ }^{75}$ This case of "genital inversion" included a number of unmistakably hysterical features, including sporadic hysteriform convulsions. However, Charcot wrote this piece with Valentin Magnan, the prominent exponent of degeneration theory, and, again, he chose to subsume the clinical material in question under the diagnostic rubric of "degeneration" rather than hysteria proper. In other words, Charcot was willing,

${ }^{70}$ Op. cit., note 50 above, p. 256.

71 Op. cit., note 69 above, p. 117.

72 Case of Antoine Charnu, Bibliothèque Charcot.

${ }^{73}$ Case of Jean-Pierre Mattivet, Bibliothèque Charcot.

74 Of one youngster from the Hérault, Charcot recorded that the patient displayed "féminisme-il joue de petites filles", and of another he commented that the patient was "maigre et délicat, les muscles sont faibles, la peau est blanche". In 1883, the alienist Henri Legrand du Saulle described a visit by Charcot to a young adolescent male demonstrating a number of hysterical signs: " $M$. Charcot est appelé en consultation. Il remarque de suite le caractère particulièrement féminin de l'enfant qui portait une bague au doigt, aimait à se parer et à jouer à des jeux de petite fille" (Legrand du Saulle, Les hystériques: état physique et état mental, actes insolites, délictueux et criminels, Paris, J. B. Baillière, 1883, p. 19).

75 This article also includes four cases of sexual fetishism in men: Charcot and Valentin Magnan, 'Inversion du sens génital et autres perversions sexuelles', Archs Neurol., 2 pts., Jan. 1882, 3(7): 53-60; Nov. 1882, 4(12): 296-322. For a recent discussion of the case, see G. Bonnet, 'Diagnostic et mot d'esprit: à propos de la réédition de "Inversion du sens génital et autres perversions sexuelles"', L'Évolution psychiat., 1988, 53: 395-407. 


\section{Mark S. Micale}

even eager, to bring the hysteria diagnosis to members of the male sex, and this despite its ancient connotations as the most excessively "feminine" of behaviours. However, at the same time, he seems to have insisted on maintaining the traditional gender identification of his male patients, even when this required evasive diagnoses or the suppression of pertinent clinical data. ${ }^{76}$

\section{IV}

Medical theory is comprised of three basic components: an explanation of disease causation, a model of symptomatology, and a programme of therapeutics. Charcot's aetiological theory of hysteria consisted of a rather uncomplicated combination of underlying constitutional factors and short-term triggering mechanisms. Throughout the second half of the nineteenth century, French and Italian psychological medicine was dominated by a severe doctrine of hereditarian determinism. "Heredity will tell you almost everything", Charcot wrote summarily in 1879, including, he believed, the origins of nervous and neurological disease. ${ }^{77}$ Subscribing to the dominant degenerationist theories of Lucas, Morel, and Moreau de Tours, Charcot believed that his hysterical patients possessed from birth a latent flaw or defect of the nervous system-a tare nerveuse - that at all times was waiting to be activated by appropriate circumstances. ${ }^{78}$ In an age of thoroughgoing medical materialism, this constitutional susceptibility to nervous disease was thought to possess an organic reality in the form of a spinal lesion or intracranial tumour. However, to their endless intellectual frustration, Charcot and his contemporaries were unable upon post-mortem examination either to locate the actual anatomical site of the abnormality or to determine the nature of the pathophysiological process. They speculated widely as to whether this defect involved a structural lesion, a nutritional deficiency, a molecular alteration, or an electrophysiological imbalance. But their ideas, despite the technical, somaticist language in which they were cast, remained wholly speculative. Charcot's solution to "the problem of the missing lesion" was to postulate the existence of a "functional" or "dynamic" lesion. By this, he seems to have meant a kind of diffuse, physiological abnormality of the nervous system that could not be detected directly, but that nonetheless had a physical, most likely cortical, substratum. ${ }^{79}$ With refinements in diagnostic technique, Charcot felt certain that the organic basis of the

\footnotetext{
${ }^{76}$ Robert Nye has suggested that the search for a patient population with a securely masculine identity may have furnished an additional reason for Charcot's selection of patients from the working classes (personal communication to the author, 4 January 1987).

${ }_{77}$ Legons du mardi, vol. 2, lesson 18, (19 March 1889), p. 420.

${ }^{78} \mathrm{P}$. Lucas, Traité philosophique et physiologique de l'hérédité naturelle, 2 vols., Paris, J. B. Baillière, 1847; B. A. Morel, Traité des dégénérescences physiques, intellectuelles et morales de l'espèce humaine, Paris, J. B. Baillière, 1857; J. J. Moreau de Tours, La psychologie morbide dans ses rapports avec la philosophie de l'histoire, Paris, Masson, 1859. The major exponent of degenerationist theory in late nineteenth-century France-and a close friend and occasional co-author of Charcot-was Valentin Magnan whose major text, Les dégénérés: état mental et syndromes épisodiques, appeared in 1895.

${ }^{79}$ Charcot's use of these terms was by no means unambiguous. While the concepts of "functional" and "dynamic" disorders have assumed purely psychiatric significations in the twentieth century, they remained a hundred years ago entirely within the organicist paradigm of the time. Charcot's belief that "functional" lesions possessed a definite, if undetermined, materiality is clearly established in "Médecine empirique et médecine scientifique', Oeuvres complètes, op. cit., note 29 above, vol. 7, pp. xxiii-xxiv; $L M S N$, vol. 3, lecture 21, p. 321; and 'Des paralysies', op. cit., note 37 above, p. 491.
} 


\section{Charcot and the idea of hysteria in the male}

functional neuroses would be discovered ${ }^{80}$ It was a solution to the problem that was more verbal than substantive.

In the period immediately preceding the rediscovery of Mendelian genetics, the exact mechanism of transmission of hereditary traits from generation to generation remained unknown; but it seemed empirically self-evident to Charcot and his contemporaries that hysteria was carried through the family. The disease, they believed, could pass unilinearly, without changes in form, from generation to generation; or by skipping generations (similar to our concept of recessive inheritance); or through "transformational heredity", whereby nervous defects appeared in successive generations but in altered pathological forms. The notion of heredity by transformation, a nineteenth-century novelty, allowed hysteria to occur in tandem with a remarkably wide range of other medical and social "pathologies". Furthermore, French degenerationist theory reached its most expansive form in the first half of the $1880 \mathrm{~s}$, the very period when the literature on male hysteria was emerging. In 1884, Charles Féré detailed the endless interrelations of hysteria with chorea, epilepsy, paralysis agitans (Parkinson's disease), multiple sclerosis, asthma, gout, rheumatism, locomotor ataxia, and general paralysis of the insane. ${ }^{81}$ Many of Charcot's narratives of male hysterics, like story lines from a Rougon-Macquart novel of Émile Zola, begin with elaborate genealogical trees full of interconnecting cases of these conditions as well as of alcoholism, suicide, criminality, and insanity. Charcot's male hysterics, then, were part of Férés "great neuropathic family" of society.

As Leston Havens has observed, "So often the [medical] investigator indicates his etiological biases by the clinical material he gives first." 82 Typically, Charcot's case histories of male hysteria begin with the search for hereditary antecedents. If a precedent could not be found in the immediate parental line, Charcot searched wider on the family tree. A suicidal sister or grandfather with gout provided ample indication of a proclivity to pathology. ${ }^{83}$ In a sense, the most striking aspect of the Salpetrian use of the doctrine of morbid heredity was the discrepancy between its clinical and theoretical sufficiency. Even with his far-reaching definition of the concept, Charcot in his printed cases of the disorder was able to locate clear hereditary precedents for only about 38 of his male patients, or 62 per cent of the total. Like Kuhnian "anomalies" in a dominant scientific paradigm, the nearly 40 per cent of the cases that remained unaccounted for might be expected to have compelled Charcot to seek causal explanations elsewhere or at least to question the adequacy of degenerationist theory. But this did not happen. When he was unable to establish a

\footnotetext{
${ }^{80}$ Georges Haberberg has characterized Charcot's functional lesion as "pre-organic" ('De Charcot à Babinski: Etude du rôle de l'hystérie dans la naissance de la neurologie moderne', doctoral diss., Créteil Medical Faculty, 1979, p. 57).

${ }^{81}$ Charles Féré, 'La famille névropathique', Archs Neurol., Jan.-March 1884, 7(19-20): 1-43, 173-91, with remarks concerning hysteria on pp. $11 \mathrm{ff}$.

82 Leston L. Havens, 'Charcot and hysteria', J. nerv. ment. Dis., 1965, 141: 506.

${ }^{83}$ Charcot's persistent interrogation of his hysterical male patients in search of the smoking family gun extended at times to ludicrous lengths. See the case of an unnamed 21 -year-old man in the Leçons du mardi (vol. 1, lesson 11, pp. 209-13) in which he finds evidence of the hysterical diathesis in the fact that the patient's paternal uncles were nervous.
} 
hereditary pathogenesis, Charcot attributed this to lack of information regarding the patient's background or to suppression by the patient of embarrassing facts about family history. For two generations of French neurologists and psychiatrists, Morelian degenerationism provided an easy and comprehensive aetiological model, and I have not found a single statement in the French literature on hysteria from the 1870 s and 1880 s that challenged the degenerationist dogma. ${ }^{84}$

The exact theoretical relationship between hysteria and degeneration was a subject of debate among French doctors at the time. Some researchers maintained that hysteria and degeneration were totally separate realities, while others believed that degeneration was a comprehensive biological reality of which hysteria represented only one dramatic manifestation. ${ }^{85}$ Still other authors suggested that the two phenomena existed on a single continuum of severity, with hysteria, in acute cases, eventually collapsing into out-and-out degeneracy. Salpêtrians most often subscribed to this last view. Jules Déjerine, who addressed at length the question of morbid heredity and nervous disease, contended that, among the different neuropathies, hysteria was the easiest to combine with other disease forms as well as the most highly heritable ${ }^{86}$ Moreover, Charcot maintained that, within the domain of hysterical illness, the neuropathic charge was especially intense in the masculine form of the disease. Déjerine, writing as a young doctor still strongly influenced by Charcot, explained:

If grave heredity is found in female hysterical patients, it appears in a still much more accentuated form in male hysteria. Alcoholism, hysteria, epilepsy, insanity, suicide of the father or grandfather; hysteria, nervousness, eccentricity, madness in the mother; hysteria, insanity, and chorea in the more distant relations [chez les collatéraux]. This is the picture that results from the observations of male hysteria published in recent years and which is especially demonstrated by the observations at the Service of Professor Charcot. ${ }^{87}$

Furthermore, Charcot maintained that in the parental transmission of male hysteria, the maternal contribution was direct and the paternal indirect. In other words, an alcoholic, epileptic, or syphilitic father, through transformational heredity, could generate hysteria in a male child; but the disorder could be conveyed directly only from the mother. "Thus", Charcot wrote in 1885 , "hysteria in the mother frequently begets hysteria in the son". ${ }^{88} \mathrm{He}$ provided no scientific explanation for this matrilineal theory.

In hereditarily predisposed persons, the diathèse nerveuse existed from birth in a state of indefinite dormancy. In roughly a quarter of Charcot's cases of male hysteria,

\footnotetext{
${ }^{84}$ Indispensable for an understanding of the uncritical adherence of alienists in France to these ideas is Ian Dowbiggin, 'Degeneration and hereditarianism in French mental medicine, 1840-1890: psychiatric theory as ideological adaptation' in W. F. Bynum, Roy Porter, and Michael Shepherd, (eds.), The anatomy of madness, vol. 1, People and ideas, London, Tavistock, 1985, pp. 188-232.

${ }^{85}$ For an expression of this second view, by a student of Magnan, see Jacques Roubinovitch, Hystérie mâle et dégénérescence, doctoral diss., Paris Medical Faculty, 1890.

86 J. J. Déjerine, L'hérédité dans les maladies du système nerveux, Paris, Asselin \& Houzeau, 1886, p. 125.

${ }^{87}$ Ibid., p. 121 . See also p. 125. This was also the judgment of Féré, in op. cit., note 81 above, p. 13.

${ }^{88}$ Op. cit., note 69 above, p. 115 . See as well Charcot's instructions regarding the separation of hysterical boys from their mothers in Leçons du mardi, vol. 1, lesson 11, p. 208.
} 


\section{Charcot and the idea of hysteria in the male}

the disorder supervened spontaneously. However, most of his cases involved constitutionally susceptible but previously asymptomatic individuals whose illnesses developed as the result of a precipitating event or aggravating circumstance. While the primary cause of hysteria -heredity - was uniform, the inciting, secondary causes were innumerable. In 1889, Charcot's student Georges Guinon published a 400-page book detailing the many agents provocateurs of the disease. ${ }^{89}$ According to Guinon's catalogue of causes, physical illnesses of all sorts, especially infectious diseases, could present "a morbid opportunity" for the onset of hysteria. ${ }^{90}$ Similarly, Charcot and Guinon believed that alcoholism provided one of the most powerful provoking agents. In the medical histories of over a third of Charcot's male cases (22 patients or 36 per cent), excessive drink figures prominently. Unique among causal factors, chronic alcoholism was capable of operating in both provocative and originative roles. It was commonly the occasional cause of the disorder in men with a defective hereditary endowment; but, over time, it also possessed the ability with individuals who were previously "non tarë" to produce "an acquired predisposition" to nervous disease. $^{91}$

The greatest number of Charcot's cases of hysteria in men, however, were set in motion through the destructive influence of a physical trauma. This brings us to one of the most scientifically significant aspects of Charcot's work, the concept of "traumatic hysteria". Charcot's writings on this topic should be seen in the context of a sequence of nineteenth-century European, particularly British, texts concerned with the neurological and psychiatric results of minor head and spinal injury. This line of enquiry began in the 1830s with the work of the surgeon Benjamin Brodie on "local nervous affections" and extended through the century in writings by Hocken (1842), Todd (1856), Althaus (1866), Skey (1867), Paget (1873), and Anstie (1874).$^{92}$ During the $1880 \mathrm{~s}$, research in this area proceeded in the Anglo-American literature on so-called railway spine (Erichsen, Page, Putnam, and Walton) and in the writings of the German neurologists Oppenheim, Thomsen, and Strümpell on "post-traumatic neurosis". In the generation following Charcot's death, European military physicians returned to the subject through the investigation of shell-shock and the "war neuroses". 93

Charcot combined the lessons of the best British work on this theme with a French clinical sensibility and brought the two to bear on the study of hysteria in men. The nature of the precipitating physical traumas in Charcot's male cases varied greatly. The patient "Mar.", for instance, a young baker's apprentice, experienced his first

\footnotetext{
${ }^{89}$ Georges Guinon, Les agents provocateurs de l'hystérie, Paris, Bureaux du Progrès Médical, Delahaye \& Lecrosnier, 1889.

90 Ibid., pp. 72-119 and Charcot, Leçons du mardi, vol. 2, lesson 19, p. 437.

91 Charcot explained this point in ibid., lesson 2, p. 35 and lesson 5, pp. 93-4.

92 Charcot's intellectual debt to the English surgical and neurological school, a topic which deserves further investigation, is revealed clearly in 'De l'influence des lésions traumatiques sur le développement des phénomènes d'hystérie locale' (1878), Oeuvres complètes, op. cit., note 29 above, vol. 1, pp. 449-58.

${ }^{93}$ Portions of the history of this research have been discussed in Harold Merskey, 'Hysteria: the history of an idea', Can. J. Psychiat., 1983, 28: 428-33; George Drinka, The birth of neurosis: myth, malady and the Victorians, New York, Simon \& Schuster, 1984, ch. 5; Esther Fischer-Homberger, Die traumatische Neurose: vom somatischen zum sozialen Leiden, Vienna, Hans Huber, 1975, pp. 105-70; and Michael Trimble, Post-traumatic neurosis: from railway spine to whiplash, New York, John Wiley \& Sons, 1981.
} 


\section{Mark S. Micale}

hysterical attack two weeks after he had been assaulted and stabbed on the street one night. "Greff.", age 31, developed an eye twitch and severe motor dysfunctions subsequent to an accident on a fishing trip in which he almost drowned. And two other middle-aged males, "D...cy" and "Augustin H.", responded with psychogenic paralyses when they were caught in thunderstorms and nearly struck by lightning. 94 In most cases, these traumatic experiences took the form of work-related accidents. The single most frequent secondary cause involved train crashes. Five of Charcot's cases were of men engaged as train engineers, freight handlers, or construction workers on the rail lines who were caught in train collisions. ${ }^{95}$ Other men underwent traumatic experiences in comparable settings: a blacksmith burned his hand and forearm with a hot iron; a clerk in an oil factory was nearly crushed to death by falling metal storage barrels; a bricklayer fell two floors from his scaffolding; a ditchdigger was struck in the face with a shovel while unloading a wagon; a chimney cleaner broke his wrist as he fell from a ladder.

Moreover, Charcot showed-and he was among the first to do so-that certain manifestations of hysteria could result from excessive exposure to chemicals in the environment. Three of his cases of masculine hysteria were examples of what one Charcot student called "toxic hysteria". 96 In his demonstration of 6 November 1888 , for instance, Charcot presented the case of "P...on". Sixty-three years old, "P...on" had worked for many years in a rubber manufacturing plant in the outskirts of Paris. One day when breathing carbon disulphide fumes from a vulcanizing solution, "P...on" began to choke, broke out into sweats, and lost consciousness. In the following days, he developed a mild spasm on the right side of his face with numbness in his right arm and leg, leading to a full hemiplegia, and accompanied increasingly by insomnia and a high level of agitation. ${ }^{97}$ Two weeks later, Charcot presented two cases in which lead poisoning, in a house-painter and a metal sifter, operated as the exciting cause of hysterical disease. ${ }^{98}$

The cases cited above involved physical accidents; but, in each instance, Charcot ultimately judged the post-traumatic symptoms to be hysterical in nature. Above all, he noted that their severity and tenacity bore little relation to the nature and intensity of the physical injury. The "traumas" in these cases ranged from life-threatening train accidents to a trifling cut on the finger. Symptoms sometimes disappeared as spontaneously as they had arisen, in a matter of hours, while at other times they persisted for months or even years without indication of organic impairment. In their

${ }^{94}$ LMSN, vol. 3, lecture 19, 280-4; Leçons du mardi, vol. 2, lesson 12, 261-5; ibid., lesson 19, pp. 436-62; and ibid., Appendix III, pp. 543-8.

${ }^{95}$ LMSN, vol. 3, lecture 23, pp. 370-85; ibid., Appendix I, pp. 458-62; Leçons du mardi, vol. 2, lesson 7, pp. 131-9; ibid., Appendix I, pp. 528-35; Clinique des maladies, op. cit., note 36 above, vol. 1, lecture 3, pp. 61-4.

96 Paul Berbez, 'L'hystérie toxique', Gaz. Hôp., 14 Jan. 1888, 61(6): 45-50.

97 Leçons du mardi, vol. 2, lesson 3, pp. 43-52.

98 Ibid., lesson 6, pp. 121-5. See the similar case of "Kauff..." op. cit., note 36 above, vol. 2, Appendix II, pp. 461-72. As often happened, a lecture or two on a subject by Charcot served to generate from other doctors and students a complete sub-literature. See, for instance, Pierre Marie, 'Sulfure de carbone et hystérie', Gaz. hebd. Méd. Chir., 23 Nov. 1888, 25(47): 743-6; Destay, Études sur la paralysie mercurielle, doctoral diss., Paris Medical Faculty, 1887; Plessard, Contribution à l'étude des rapports de l'hystérie et du saturnisme, doctoral diss., Paris Medical Faculty, 1888; and Guinon, op. cit., note 89 above, pp. 135-205. 


\section{Charcot and the idea of hysteria in the male}

ability to incapacitate an individual for long periods of time, Charcot knew these hysterical infirmities were as real, psychologically and subjectively, as those entailing actual structural damage. He observed further that, following an incident of this sort, many patients temporarily experienced a partial or total memory loss surrounding the event ("post-traumatic amnesia", in current medical terms), and he conjectured that there was frequently an inverse relationship between duration of loss of consciousness and degree of subsequent pathology. 99

In the period 1885-88, Charcot's work on masculine hysteria was practically synonymous with the investigation of traumatic hysteria. ${ }^{100}$ This work should be understood both scientifically and socially. Taken together, his writings on this topic represent a penetrating exploration of the elaborate functional sequelae of minor bodily injury. Military doctors during the First World War, confronted with an epidemic of psychogenic paralysis, blindness, and amnesia among soldiers on the front lines, would return to Charcot's writings on male hysteria. And many of his findings on the neuropsychology of trauma have been confirmed by subsequent medical research. This is also true of his work on substance-induced neuroses. In time, most of these cases would be separated from the hysteria diagnosis as distinct and demonstrably organic disorders; but Charcot's acute clinical depiction of these syndromes, and the spate of research they inspired, pointed the way toward the current concept of the toxic psychoses.

More than any other aspect of his theory, Charcot's commentary on the secondary causes of male hysteria expressed a number of social and cultural concerns of the day. His strong emphasis on the deleterious effects of alcohol, for instance, goes back in part to Morel and Magnan. But the particular pathogenic potency that he ascribed to this factor also reflected the great increase in public and professional distress over the evils of chronic drunkenness among the working classes, which characterized France during the early years of the Third Republic. ${ }^{101}$ Similarly, Charcot's emphasis on the railway as a dramatic setting for nervous breakdowns must be seen against the expansion of the railways in France. The large number of Charcot's cases involving this form of travel almost certainly register contemporary cultural anxieties about rapid mechanized transportation and the unprecedented and uncontrollable technological change that it symbolized. ${ }^{102}$

\footnotetext{
${ }^{99}$ LMSN, vol. 3, Appendix I, p. 443; Leçons du mardi, vol. 1, lesson 16, p. 297; ibid., vol. 2, lesson 7, p. 134; Guinon, op. cit., note 89 above, p. 49.

100 For a guide to the large Salpêtrian literature on traumatic hysteria, see the bibliography of ibid., pp. 373-89.

101 Gérard Jacquement, 'Médecine et "maladies populaires" dans le Paris de la fin de XIXè siècle' in Recherches. Ville, habitat et santé du XIXè siècle, Dec. 1977, no. 29, pp. 349-64; Susanna Barrows, 'After the Commune: alcoholism, temperance, and literature in the early Third Republic' in John Merriman (ed.), Consciousness and class experience in nineteenth-century Europe, New York, Holmes \& Meier, 1979, pp. 205-18; Allan Mitchell, 'The unsung villain: alcoholism and the emergence of public welfare in France, 1870-1914', Contemp. Drug Problems, Fall 1986, pp. 447-71.

102 Émile Zola's novel La bête humaine (1889), which dramatized the theme of train locomotion as a destructive force in the modern world, also appeared at this time. The urgent medical concern in the nineteenth century with the health hazards of modern rail travel is the subject of Esther FischerHomberger, 'Die Büchse der Pandora: Der mythische Hintergrund der Eisenbahnkrankheiten des 19ten Jahrhunderts', Sudhoffs Arch., 1971, 56: 297-317.
} 
Above all, Charcot's study of the traumatic hysterias also coincided with a period of rapid and very extensive industrialization in France that multiplied the number of industrial accidents. As a senior physician at a hospital in the largest urban centre of France and situated in a working-class district adjacent to the Gare d'Austerlitz, Charcot was exposed to these cases in large numbers. ${ }^{103}$ Moreover, with the rise of a new capitalist society came an assertive workers' movement, which in France was achieving its first legal and political advances in the 1880s and 1890s. An important aspect of early socialist programmes throughout Europe involved the campaign for legislation to protect workers. ${ }^{104}$ During the last two decades of the century, the subject was bitterly debated in the French legislature, and, in 1897, the Loi sur les accidents du travail was finally passed. This law provided many categories of workers (including railway employees and most factory workers in the cities) with a statutory right to financial compensation from their employers in the event of serious bodily injury at work. ${ }^{105}$ Charcot never openly referred in his medical writings to contemporary legislative debates, and I have found no mention of his name in the French parliamentary reports on the issue. Yet, in the political campaigns of the day for "industrial hygiene", exactly the sort of medical material presented in his writings on male hysteria was cited time and again by social activists for overtly political purposes. As a physician of international authority, Charcot, simply by recounting sympathetically cases that demonstrated a direct link between working conditions and debilitating disease, may have been providing a social and political commentary that would have been understood at once by his medical and lay contemporaries. ${ }^{106}$

If physical traumata provided the most common secondary cause of male hysteria, what was the role of sexual and psychological factors in Charcot's aetiological model? On first reading today, it appears, as it did to Charcot initially, that the medical damage in these cases was the direct result of a physical accident. But Charcot noticed a number of peculiar clinical features in many of these cases. As I have mentioned, he was struck by the variations in the periods between the time of the trauma and the onset of hysterical symptoms, and by the curious incommensurability of the intensity of the physical trauma with these symptoms. Furthermore, like Brodie and Paget before him, he observed the phenomenon of non-anatomical regional sensory loss. The anaesthesias and hyperaesthesias that many of his patients reported corresponded in location and extent, not to the actual distribution of nerves and muscles in the body, but to the popular segmental understanding of anatomy. These observations led Charcot tentatively to move beyond a strictly somaticist interpretation of the disorder. On closer examination, we find that in most of

\footnotetext{
${ }^{103}$ Charcot at one point referred to a case of industrial lead poisoning as "un nouvel exemple de ces cas aujourd'hui devenus presque vulgaires" (Leçons du mardi, vol. 2, lesson 6, p. 121).

104 In Britain, Parliament passed the first Employers' Liability Act in 1880, followed in 1897 by the more comprehensive Workmen's. Compensation Act. In 1885, the German Reichstag implemented the Industrial Injury Law. And in 1891, the first International Congress for Workers' Accidents was held in Amsterdam.

${ }^{105}$ Additional historical information may be found in V. P. Comiti, 'Les maladies et le travail lors de la révolution industrielle française', Hist. Philos. life Sci., 1980, 2: 215-39.

106 With this in mind, consider the case of "Charv.", who developed "hysterical hip" following a machine accident at work. Charcot narrated the case with sympathy and cited with approbation a recent decision by the company involved to supply a generous pension to the disabled man and his family ( $L M S N$, vol. 3 , lecture 24 , p. 397).
} 


\section{Charcot and the idea of hysteria in the male}

Charcot's cases of masculine hysteria, it is not the physical injury per se that produced the disease; rather, the mental experiencing of the traumatic episode, the emotional and ideational accompaniment to the event, carried a pathogenic charge and led to the development of the disorder. ${ }^{107}$ To be sure, Charcot was too skilful a neurologist to ignore the possibility of real structural damage. Indeed, he enjoyed demonstrating to audiences those complicated cases in which both a physical injury and its emotional concomitants contributed to produce mixed "hystero-organic" forms of the disorder. ${ }^{108}$ But, in most of his cases, it was the "the great psychical shaking up-le grand ébranlement psychique"-that provided the decisive causal element: ${ }^{109}$

The nervous shock or commotion, the emotion almost unavoidably inseparable from an often life-threatening accident, is sufficient to produce the neurosis in question. The surgical effect of the traumatism, or, in other words, the causing of a wound or contusion ... is not a necessary element for the development of the disease, although it can contribute to it taking on a grave form. ${ }^{110}$

In several instances, Charcot broadened the concept of trauma still further by dispensing altogether with the threat of a physical injury. On 17 April 1888, for instance, "Pasq.", a 51-year-old Spaniard living in Paris, was brought by his family in an agitated state to the walk-in clinic of the Salpêtrière. The patient was unable to talk-he mimed his responses to Charcot during the clinical interview-and revealed upon examination a number of bizarre sensory malfunctions. "Pasq." 's family reported that over the previous eight years the patient had also lapsed periodically into bouts of stuttering, whispering, and mutism. Charcot interviewed the man and discovered that each of these episodes had followed a difficult domestic experience: once when the patient quarrelled violently with his wife, a second time when the wife hid their rent money for a month, and a third when she absconded with their life savings. ${ }^{111}$ In the second volume of the Leçons $d u$ mardi, events leading to the development of hysterical symptoms in male patients include the threat of a fist fight with a friend, the death of a wife and daughter, rejection of a marriage offer, viewing a cadaver in a hospital, receiving a letter of strong parental reproach, and watching a thunderstorm. In each of these cases, it was ultimately the power of an idea or emotion-fear, rage, grief, anxiety—that "caused" hysteria. ${ }^{112}$

\footnotetext{
${ }^{107}$ I believe that Léon Chertok was the first person to make this point about Charcot's work, in 'On objectivity in the history of psychotherapy', J. nerv. ment. Dis., 1971, 153: 73.

108 'Sur un cas de coxalgie hystérique de cause traumatique chez l'homme (2)', $L M S N$, vol. 3, lecture 24, pp. 388,390 . Charcot believed that these "pathological hybrids" were especially common in males.

109 'A propos d'un cas d'hystérie masculine', op. cit., note 36 above, vol. 1, lecture 14, p. 305.

110 Lefons du mardi, vol. 2, lesson 2, (30 Oct. 1888), p. 30.

111 Ibid., vol. 1, lesson 18, pp. 348-53.

112 The progressive psychologization of the trauma concept during the late nineteenth century, of which Charcot was only a part, reached a culmination in early psychoanalytic theory. In Freud's writings of the 1890 s, the idea of traumatic aetiology would be elevated from secondary to primary status, linked to the theories of psychosexual motivation and unconscious repression, and pushed deep into the emotional past of the individual. See Sigmund Freud and Josef Breuer, Studies on hysteria (1895) in The standard edition of the complete psychological works of Sigmund Freud, 24 vols., translated from the German under the general editorship of James Strachey in collaboration with Anna Freud, London, Hogarth Press, 1953-74, vol. 2, especially pp. 5-6, 8-16.
} 
Precisely how an idea or emotion was transformed into a bodily symptom-how, in Freud's later phrase, we get "from a mental process to a somatic innervation"-was an old and very thorny question. ${ }^{113}$ For Charcot, we sense, such a line of investigation was intellectually uncongenial. ${ }^{114}$ On one occasion, however, he attempted to explore the question. In March 1886, Charcot delivered a lecture entitled 'Two new cases of hystero-traumatic paralysis in men'. ${ }^{115}$ One of the cases concerned "Le Log.", a 29-year-old Breton recently come to Paris to work as a florist deliveryman. While crossing the Pont des Invalides with a wheelbarrow one afternoon, "Le Log." was sideswiped by a passing horsedrawn carriage. The man sustained only minor physical injuries but lost consciousness momentarily. When he appeared at the Salpêtrière several days after the accident, "Le Log." presented an eccentric panoply of symptoms, including headaches, trembling hands, amnesiac episodes, hypersensitivity of the scalp, and complete tactile and thermal anaesthesias in the lower half of his body except for his toes. After reviewing the clinical facts of the case, Charcot enquired into "the mechanism of pathology" of the paralysis. The emotional shock from the accident, he hypothesized, created in the patient "an intense cerebral commotion", which, he suggested in language more redolent of Janet than Charcot, caused an "obnubilation of consciousness" and a "dissociation" of "the ego". Charcot attempted to envision this mental process by drawing analogies between traumatic hysteria and states of drunkenness, drug intoxication, and the somnambulic stage of the hypnotic trance. ${ }^{116}$ Precisely what transpired intrapsychically in this last, quasi-hypnotic state remained vague, and we see Charcot at this point grappling for a new, non-neurological vocabularly with which to account for the process. He conjectured that, in this state of increased psychological suggestibility, the strong physical sensation associated with the trauma was somehow reproduced as a mental representation, which then became setwe might say "functionally fixed"-in the mind of the individual. He referred to this physical and mental idée fixe as the result of "an involuntary and most often unconscious auto-suggestion", and he described the fertile period of delay between physical trauma and hysterical symptom as "a sort of incubation stage of unconscious mental elaboration". 117

In the last two decades, historians in search of the intricate intellectual origins of psychoanalysis have considerably overstated the psychological component in Charcot's thinking. Charcot's central scientific agenda, we should remember, was a comprehensive descriptive clinical neurology and not a theoretical dynamic psychiatry. ${ }^{118}$ His consideration of "Le Log."'s symptoms is limited to a six-page

\footnotetext{
${ }^{113}$ Freud, 'Notes upon a case of obsessional neurosis' (1909) in Standard edition, ibid., vol. 10, p. 157.

${ }^{114}$ Charcot once described the mind-body question in medicine as "ce problème hérissé de difficultés de tout genre" (LMSN, vol. 3, lecture 21, p. 334).

115 'Deux nouveaux cas de paralysie hystéro-traumatique chez l'homme', ibid., Appendix I, pp. 441-59.

${ }^{116}$ Charcot found the functional parallel between the mental states of hypnosis (which he regarded as an induced neurosis) and post-traumatic hysteria to be a compelling one, and he made it often. See ibid., lecture 21, pp. 335-6; and lecture 24, p. 392.

${ }^{117}$ Charcot's "psychological" analysis of "Le Log." appears in 'Deux nouveaux cas de paralysie hystéro-traumatique chez l'homme', ibid., Appendix I, pp. 450-6. "Auto-suggestion involontaire" is from op. cit., note 36 above, vol. 1, lecture 2 , p. 32.

${ }^{1} 18$ Charcot's proper place on the continuum of psychophysical causality has been a matter of debate among historians. For the standard emphasis on the pre-Freudian aspects of his thought, see A. R. G.
} 


\section{Charcot and the idea of hysteria in the male}

passage in a single case history. And even in this context, we sense that behind the figure of the tentative psychological theorist lurks the disciplined mind of the pathological anatomist. "Il faut penser anatomiquement et physiologiquement", he believed to the end. ${ }^{119}$ Furthermore, a number of earlier nineteenth-century theoreticians, such as Briquet and Carter, had accorded a significantly larger aetiological role to the emotions in hysteria than did Charcot. And, by the time of his death in 1893, several authors-Janet and Grasset in France, Delboeuf in Belgium, and Benedikt, Möbius, Strümpell, Breuer, and Freud in Germany and Austria-had gone farther in exploring the ideogenesis of hysteria. At the same time, Charcot's observations on this matter are significant, and they were made specifically in reference to his work on traumatic male hysteria. His neuropsychological speculations impart theoretical depth to his general clinical neurology. And his reflections on the case of "Le Log." pointed the way toward a psychological explanation of physical symptoms, i.e., a theory of conversion. ${ }^{120}$ Viewed in historical context, his remarks do provide one of the preliminary steps in the general movement of the age from somatogenic to psychogenic models of the mind.

Finally, Charcot's ideas on the place of sexuality in the production of male hysteria. From its beginnings in Graeco-Roman medicine onwards, hysteria had been linked in one way or another to inadequate, excessive, impaired, or disturbed sexuality. The nineteenth century, we have seen, witnessed a resurgence of these sexual theories. The Charcotian model at first seems a part of this revival. The best-known visual representations of Salpêtrian hysteria-the Iconographie photographique de la Salpêtrière, the etchings of Paul Richer, the Brouillet canvas-are pervaded with eroticism. ${ }^{121}$ But here, as elsewhere in the historical study of hysteria, the most familiar sources mislead.

A reading of Charcot's complete works reveals that his ideas about hysteria and sexuality were complicated. In fact, he firmly rejected a sexual pathogenesis for the disease throughout his career and in regard to both male and female hysteria. In most of his clinical reports on male patients, sexual matters are not mentioned at all. Where sexual factors are operative, it is most often in the form of physical disorders or

\footnotetext{
Owen, Hysteria, hypnosis and healing: the work of J.-M. Charcot, London, Dobson, 1971, pp. 55-123; Henri F. Ellenberger, The discovery of the unconscious, New York, Basic Books, 1970, ch. 2; and Léon Chertok and Raymond de Saussure, Naissance du psychanalyste de Mesmer à Freud, Paris, Payot, 1973, pp. 93-114. My view of the subject - that Charcot moved timidly toward psychogenic explanations through his work on select topics while remaining within the reigning neurophysiological paradigm of his time-is most in accord with Esther Fischer-Homberger, 'Charcot und die Ätiologie der Neurosen', Gesnerus, 1971, 28: $35-46$.

${ }^{119}$ Quoted in A. Lubimoff, Le Professeur Charcot: Étude scientifico-biographique, translated from the Russian by Comtesse Lydie Rostopchine, Paris, A. S. Souvorine, 1894, p. 20.

${ }^{120}$ Freud and Breuer were of course aware of the implications of Charcot's work in this direction. Writing in the 'Preliminary Communication' of 1893, they commented that "by uncovering the psychical mechanism of hysterical phenomena we have taken a step forward along the path first traced so successfully by Charcot with his explanation ... of hystero-traumatic paralyses ..." (Studies on hysteria in Standard Edition, vol. 2, p. 17).

${ }^{121}$ This feature has not gone unnoticed by scholars: Michel Foucault, Histoire de la sexualité, vol. 1: La volonté de savoir, Paris, Gallimard, 1976, pp, 74-6; Jacqueline Carroy-Thirard, 'Figures de femmes hystériques dans la psychiatrie française du XIXè siècle', Psychanalyse à l'université, 1979, 7: 313-23; Didi-Huberman, op. cit., note 2 above.
} 


\section{Mark S. Micale}

dysfunctions of the urogenital system. Charcot routinely examined the genitalia of his male patients and reported matter-of-factly on his findings. If he detected an abnormality, such as a scrotal tumour, undescended testicle, inguinal hernia, or prostatic inflammation, he tended to interpret these phenomena as sources of exacerbation for nervous disorders. He also believed that syphilitic infections could serve as secondary causes of hysterical symptoms. In a number of instances, he reported impotence, "spermatorrhoea", and anaphrodisia in his male patients. ${ }^{122}$ And several times he related hysterical neuroses in males to particular personal habits. These practices, inevitably, included the "Victorian" vices of excess and onanism. Of the 27-year-old locksmith "Gui.", for instance, he wrote that the patient's heavy drinking and "immoderate penchant for women" contributed to his condition. ${ }^{123}$ And, in the section on "personal antecedents" in the case of the metalworker "Gil.", he recorded of the patient that "from a very early age he made an abuse of coitus. He feels from time to time a sort of irresistible impulse toward women ... He is moreover an insatiable masturbator-un masturbateur frénétique."124

However, in the general intellectual history of hysteria, Charcot's remarks on this subject are noteworthy above all for their rarity and moderation. To repeat, sexuality failed to figure in any guise in a majority of his histories of hysteria in males. When it did so, it assumed a purely physical form and was always relegated to the auxiliary status of agent provocateur. In only three of his 61 cases does Charcot cite masturbation as a factor, which is remarkable given the contemporary preoccupation with the subject. Furthermore, in a number of cases, Charcot raised the question of sexuality simply to assure readers that it did not play a determining role. ${ }^{125}$ As readers of the Iconographie photographique will recall, Charcot and his students saw the sexual component in hysteria very clearly. Indeed, in the media of photographs and descriptive prose, they recorded the erotic misbehaviour of their female hysterical patients in loving and lurid detail. However, on the theoretical level, Charcot and his students demonstrated an almost wilful refusal to recognize the possible sexual dimensions of the disorder. In Guinon's exhaustive study of the secondary causes of hysteria, sexual factors occupy only four pages. ${ }^{126}$ And, in Gilles de la Tourette's three-volume compendium on hysteria, the official codification of Salpêtrian theory, the topic is not mentioned at all.

It is a curious and conspicuous omission, one that it is tempting to attribute to Victorian prudery or to a self-interested conspiracy of silence among professional

\footnotetext{
122 Leçons du mardi, vol. 1, lesson 4, pp. 62-5 and Charcot and Pierre Marie, 'Hysteria mainly hystero-epilepsy' in Daniel Hack Tuke (ed.), A dictionary of psychological medicine, 2 vols., London, J. \& A. Churchill, 1892, vol. 1, p. 637.

123 Op. cit., note 50 above, p. 272.

124 Ibid., p. 267.

125 Théodore Tarczylo has determined that the volume of nineteenth-century anti-masturbation literature in Europe and America peaked during the 1880s and 1890s: Sexe et liberté au siècle des Lumières, Paris, Presses de la Renaissance, 1983, Appendix V, pp. 297-8. In regard to Charcot's discussions of sexuality, see the case of the 24-year-old "Me...ier" (Leçons du mardi, vol. 2, lesson 9, pp. 189-98). Charcot presented extensive information about this patient, including the facts that the onset of his illness coincided with the rejection of an offer of marriage and that his symptoms included an intense genital hyperaesthesia, but then hurried to ensure readers that the case was not one of "Hysteria virilis amatoria".

${ }^{126}$ Guinon, op. cit., note 89 above, pp. 129-33.
} 


\section{Charcot and the idea of hysteria in the male}

men confronted with the aggressive eroticism of the hysteric. But these interpretations would be mistaken. In a perceptive essay of 1898 appearing in The Alienist and Neurologist, Havelock Ellis examined the changing place of sexuality in recent theories of medical psychology. ${ }^{127}$ Ellis observed that Charcot sought above all to establish hysteria as the subject of serious and legitimate study within the medical sciences. Hence, Ellis continued, Charcot strove to divorce definitively the modern diagnosis of hysteria from the old Galeno-Hippocratic model of the disease and the long train of pernicious associations that had proceeded from it. In the nineteenthcentury medical imagination, the most prominent of these stereotypes involved the image of the hysterical woman as a deceitful, adulterous, sexually treacherous creature: the hypererotic hysteric. This view, which had been embodied for some time in a string of steamy popular French novels, received added professional credence in France during the 1870s and 1880s in a body of psychiatric writing on hysteria and nymphomania. ${ }^{128}$ It was also this interpretation of the personality of the hysteric, in combination with the revived genital theory of the disorder, that contributed to the contemporary craze for gynaecological surgery. Ellis's observations, then, are entirely to the point, and they apply equally to Charcot's work with male and female hysteria. The programmatic asexualism of Charcot's writings, like that of Briquet's a generation earlier, was not the result of a medical oversight, a sign of sexual hypocrisy, or a strategy for social control. It was a calculated response to ancient but still influential aetiologies of the disease and to the more recent and disturbing tendency to attribute a libidinous and lascivious character to the hysteric. To neutralize the diagnosis sexually, then, was, in Charcot's mind, to desensationalize it, and, all-importantly, to bring it within the orbit of sober positivist science. There was, however, irony in this strategy. As Ellis and Freud realized at the time, Charcot's admirable reaction against errors and excesses past and present quickly incurred serious theoretical limitations. ${ }^{129}$ Charcot was so intent on freeing the modern hysteria diagnosis from the old genital theories that he denied any possible aetiological role whatsoever to this important area of human behaviour. And in a new and comprehensive theory just emerging at the time of his death, a reformulated psychosexual explanation of hysteria figured centrally.

\section{$\mathbf{v}$}

Of all the elements in the theory of masculine hysteria, Charcot and his students lavished most attention on its clinical manifestations. Indeed, one comes away from the Salpetrian literature with the suspicion that the exhaustive documentation of symptoms served as a substitute for aetiological and therapeutic innovation. This

\footnotetext{
${ }^{127}$ Havelock Ellis, 'Hysteria in relation to the sexual emotions', Alienist and neurologist, Oct. 1898, 19(4): 599-615, reprinted in Studies in the psychology of sex, 7 vols, Philadelphia, F. A. Davis, 1901-28, vol. 1, pp. 139-64.

${ }_{128}$ Charles Lasègue, 'Les hystériques, leur perversité, leurs mensonges', Annls méd.-psychol., series 6, July 1881, 6: 111-18; Henri Huchard, 'Caractère, moeurs, état mental des hystériques', Archs Neurol., March 1882, 3(8): 187-211; Legrand du Saulle, op. cit., note 74 above, Appendix, pp. 581-625.

129 "Formerly the sexual element in hysteria was somewhat exaggerated. There is now a tendency to unduly minimize it" (Ellis, Man and woman: a study of human secondary sexual characters, London, Walter Scott, 1894 , p. 283).
} 
emphasis reflected in part the state of the mental sciences as a whole, still highly descriptive and classification-oriented in the second half of the nineteenth century. But it also reveals the absence of a firm aetiological understanding. Throughout this period, there existed no hard-and-fast knowledge of the neuropathological or psychopathological mechanisms underlying the "functional" nervous disorders. As a consequence, Charcot was forced to define hysteria in an essentially nosographical fashion. Charcotian hysteria represented the totality of its external symptoms which Charcot believed could be grouped into symptomatological sub-groups, or syndromes, and, from here, into an independent disease entity. "What, then, is hysteria?" Charcot asked in his last essay on the subject in 1893. "We know nothing of its nature, nor about any lesions producing it. We know it only through its manifestations and are therefore only able to characterize it by its symptoms, for the more hysteria is subjective, the more it is necessary to make it objective in order to recognize it." 130

Charcot was able to get away with such a one-dimensional definition of the disorder because its symptoms were so very diverse and dramatic. In its famous fin-de-siècle form, the hysteria diagnosis, along with its sister condition neurasthenia, covered nearly the entire field of the neuroses as we understand them today, spilling over into other areas now covered by the psychoses and by organic, particularly neurological, medicine. Charcot believed that hysteria was a névrose in the nineteenth-century neurological sense of the term. Not surprisingly, then, signs of central nervous dysfunction figured most prominently in his symptomatological account of the disorder. ${ }^{131}$ The tableau clinique of hysteria in Charcot's male patients was characterized most commonly by aberrations of sensibility. Forty-eight out of Charcot's 61 male patients ( 79 per cent of the total) exhibited symptoms of this kind. The most basic of these sensory "stigmata" were anaethesias and hyperaesthesias, or exaggerations of sensibility to touch, temperature, and electricity. These derangements could be cutaneous, muscular or visceral, and affect a single organ or area-as in a facial neuralgia-or extend over the entire surface of the body. Hemianaesthesias, or losses of sensation following the precise medial line of the body, were frequent. ${ }^{132}$ Charcot devised extensive tests to detect these sensory pathologies and recorded the results on elaborate "body maps" for each patient (figure 1). To these algias and aesthesias were added abnormalities of the five senses. Visual disturbances were most frequent and provided, Charcot thought, a particularly dependable diagnostic indication. They took the form of blindness, partial or total colour-blindness, reduction of light perception (amblyopia), double vision, and concentric narrowing of the visual field. ${ }^{133}$ Charcot also believed that loss of sense of taste was typical of male hysteria. ${ }^{134}$

\footnotetext{
${ }^{130}$ Charcot and Marie, op. cit., note 122 above, p. 628.

131 The best review of the symptomatology of Charcotian hysteria is ibid., pp. 629-39.

132 The specialist of the day on this subject was Albert Pitres, dean of the Bordeaux Medical Faculty and the main exponent of Charcot's work in that city. See Pitres's monograph Des anesthésies hystériques, Bordeaux, Davezac, 1887.

${ }^{133}$ Henri Parinaud, 'The ocular manifestations of hysteria' in William F. Norris and Charles A. Oliver (eds.), System of diseases of the eye, 4 vols., London, J. B. Lippincott, 1900, vol. 4, pp. 727-69.

${ }^{134}$ Legons du mardi, vol. 2, lesson 15, p. 352.
} 


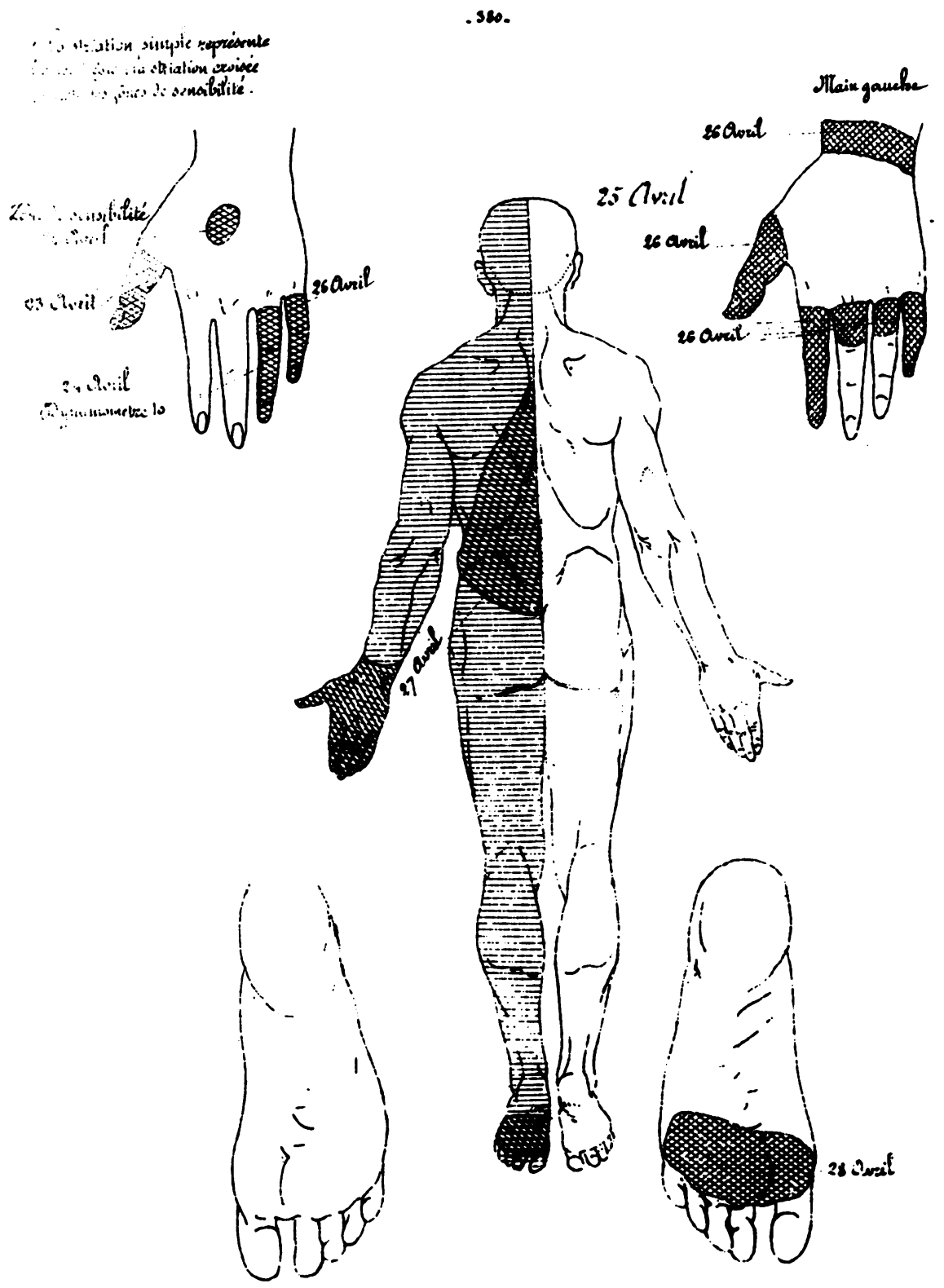

Figure 1. Anaesthetic and hyperaesthetic areas of male hysterical patients. From Charcot's Lefons du mardi, vol. 1 (1887), p. 380. (Photograph: Wellcome Institute Library, London.) 


\section{Mark S. Micale}

A second major category of hysterical symptoms involved motor impairments, including paralyses, contractures, and spasms of all sorts. Twenty-nine of Charcot's male patients ( 47 per cent) suffered from this type of infirmity. These disorders could affect a single muscle or group of muscles or could develop as paraplegias or hemiplegias. Flaccid paralyses, in which an arm or leg hung motionless, also occurred occasionally. Contractures of the extremities, Charcot found, were for some reason particularly intractable with male patients, in whom a limb could maintain a position of complete rigidity for months or years. ${ }^{135}$ Furthermore, unilateral deviations of the tongue muscles, or glosso-labial spasms, were not uncommon. In the category of hysterical motor disorders, Charcot also once discussed a curious syndrome in which a male patient, with no perceptible loss of muscular ability, was unable to walk or stand upright. ${ }^{136}$

These classic neurological somatizations formed the core of the hysterias in Charcot's male patients. For Charcot, these were the only pathognomonic signs. Beyond this, he knew that hysteria was, as Sydenham had said, a kind of "medical chameleon" that could deceptively assume the form of a multitude of ailments. In Charcot's male cases, the primary symptoms listed above were accompanied at various times by dizziness, headaches, fevers, back pain, nose bleeds, eye twitches, diarrhoea, anuria, dysuria, rapidity of pulse, chest palpitations ("hysterical heart"), chest pain ("hysterical angina"), trembling of the hands and legs, pain in the joints, redness or paleness of the skin, numbness and tingling in the extremities, and increased secretion of sweat and saliva. There is scarcely a pathological sign that at one time or another does not appear in these cases.

Charcot also believed that hysteria was closely connected with the respiratory and upper digestive systems. In nearly half of his male patients, he discovered anaesthesias of the epiglottis, which caused a peculiar suppression of the gagging reflex. His writings include as well several dramatic examples of dyspnoea, uncontrollable coughing, thoracic pain, and "spasms of the oesophagus". ${ }^{137}$ And he also often found in these men a number of language disorders, such as slurring of speech, stuttering, aphonia, and hysterical mutism. ${ }^{138}$ In three cases, he described in detail the phenomenon of coprolalia, characterized by an involuntary and compulsive urge to utter obscenities in public and accompanied by convulsive tics and obsessive daily thoughts and practices. ${ }^{139}$ These cases, presented initially under the heading of male hysteria, are among the earliest accounts of Tourette's syndrome. ${ }^{140}$

\footnotetext{
135 Paul Richer, Paralysies et contractures hystériques, Paris, Doin, 1892; and Gilles de la Tourette, op. cit., note 40 above, vol. 1 , ch. 10; vol. 3 , ch. 12 and 13 .

${ }^{136}$ Leģons du mardi, vol. 1, lesson 12, pp. 227-9. This was one of the first descriptions in medical history of astasia-abasia.

${ }^{137}$ Case of "Guénin", Countway Medical Library, Manuscripts Division. Charcot, Folio C96; Charcot and Marie, op. cit., note 22 above, pp. 635-6; and Gilles de la Tourette, op. cit., note 40 above, vol. 2, ch. 14.

${ }^{138}$ LMSN, vol. 3, lecture 26, pp. 422-38; ibid., Appendix V, pp. 483-512; Leçons du mardi, vol. 1, lesson 19, pp. 357-63; and ibid., vol. 2, lesson 12, pp. 265-9.

139 Ibid., vol. 1, lesson 4, pp. 60-2; ibid., lesson 11, pp. 209-13; ibid., vol. 2, lesson 1, pp. 13-17. See also 'Des tics et tiqueurs', Tribune méd., 25 Nov. 1888, 19(1058): 571-3.

140 Christopher Goetz has suggested that, although this disorder is named after Gilles de la Tourette, Charcot's student mainly gathered and published the clinical observations of his teacher: Charcot, the
} 


\section{Charcot and the idea of hysteria in the male}

Needless to say, the highly neurological nature of Charcot's hysteria presented major diagnostic difficulties. For clinicians a century ago no less than today, hysteria was necessarily a "diagnosis of exclusion". Given the formidably "neuromimetic" abilities of the hysterical patient, a responsible diagnosis required at the outset a close consideration of all possible organic causation. ${ }^{141}$ Charcot was keenly aware of the difficulties of accurate diagnosis, and with his male patients he confronted the problem head-on. Indeed, increasingly through the $1880 \mathrm{~s}$, his principal intellectual interest in these cases was the challenge of differential diagnosis. Charcot lacked many basic diagnostic tools available today. Moreover, while a friend and admirer of Pasteur, Charcot really failed to understand the full implications of the Pasteurian revolution, with its new methodologies of laboratory medicine, that was taking place around him. ${ }^{142}$ Consequently, in forming judgements about his cases, he relied on purely clinical criteria. However, with his unsurpassed experience of bedside neurology, from the 1860 s and 1870 s, he was superbly equipped for such an exercise. Charcot has often been described as the "father of neurology" and as a precursor of dynamic psychiatry. Just as appropriately, he was probably the last great practitioner of French clinicism. Several of his later case studies of hysteria in the male are small masterpieces of differential diagnosis.

The 21st lecture of the Lef̧ons du mardi, for instance, is a study of the hysterical simulation of syringomyelia. In this context, Charcot presented the case of "P...eyn", a 46-year-old man who was employed as a nightwatchman at the construction site of the new Eiffel Tower. Following the unexpected death of his wife and young daughter, "P...eyn" developed a paralysed right hand and wrist accompanied by swelling, skin discoloration, and loss of sensitivity to pain and temperature (although not to touch) in the extremity. The paresis, tropic troubles, and dissociation of sensibility appeared syringomyelic in nature. But, upon further investigation, Charcot showed that the rapid onset of the symptoms and the pattern of remissions, in addition to the presence of a small sensory stigmata (loss of taste on the right side of the tongue), established the case as one of hysteria rather than a true progressive neurological disorder. ${ }^{143}$ In another case, Charcot distinguished between hysterical trembling of the legs and shaking of the extremities in cases of alcoholism, paralysis agitans, and multiple sclerosis. ${ }^{144}$ In a two-part lecture delivered in March 1889 , he probed the combination of epileptic seizures and epileptiform hysterical attacks (psychogenic "pseudo-seizures" in current medical parlance) in the same patient. ${ }^{145}$ And in still another case, he demonstrated the subtle clinical differences between functional aphonia and organic aphasia. ${ }^{146}$

\footnotetext{
clinician: the Tuesday lessons, translated from the French with commentary by C. G. Goetz, New York, Raven Press, 1987, pp. 60, 63.

${ }^{141}$ Several years before Charcot began his work on hysteria in the male, James Paget had published in the Lancet his series of essays on the concept of neuromimesis. See Paget, 'Nervous mimicry' (1873), reprinted in Sir James Paget, Selected essays and addresses, ed. Stephen Paget, London, Longmans, Green \& Co., 1902, pp. 73-144.

142 Bernard Brais, personal conversations with the author, 1987-88.

143 Lefons du mardi, vol. 2, lesson 21, pp. 516-23.

144 'Des tremblements hystériques', op. cit., note 36 above, vol. 1, lecture 3, pp. 46-69.

145 Lefons du mardi, vol. 2, lecture 17, pp. 393-9 and ibid., lecture 18, pp. 419-33.

146 LMSN, vol. 3, lecture 26, pp. 422-38. Charcot treated the differential diagnosis of hysteria and organic disease with his female patients as well. On hysteria and locomotor ataxia, see Leçons du mardi, vol. 2,
} 


\section{Mark S. Micale}

Charcot always remained keenly attentive to the possibility of real structural damage to the nervous system. Because hysteria in his male patients occurred so often in association with a traumatic physical incident, the likelihood of real injury to the brain, spinal cord, nerves, or muscles remained higher than with his female patients. Charcot was particularly interested in the differentiation of paralyses and contractures of organic and hysterical origins. His favourite pedagogical exercise for this purpose was the close and comparative symptomatological analysis of two superficially similar cases. From a rich collection, a single example will have to suffice. In May 1885, Charcot presented in juxtaposition the stories of "Porcz." and "Deb.". 147 Both men suffered from longstanding brachial monoplegias following physical accidents- "Porcz." after he had been thrown from his carriage onto the pavement and "Deb." when a steel beam fell on his shoulder. On preliminary examination, the cases appeared identical. However, with further inspection, Charcot discovered that, even several months after the accident, "Porcz." showed no atrophy of the paralysed muscles, no skin discolouration, and no reduction in muscular response to electrical stimulation. Charcot demonstrated as well that the pattern of the patient's anaesthesia formed a "glove and stocking paraesthesia" that stopped abruptly at the elbow and shoulder. On the other hand, "Deb."'s symptoms differed on each of these points. Here, the skin of the paralysed limb was cold and marked by purplish spots, and the tendon reflexes were absent. The patient's shoulder muscles revealed extensive deterioration, and the loss of movement and sensation in the extremity tapered off irregularly into the fingers and upper arm following the known distribution of nervous and muscular tissue. After reviewing the possible organic explanations of the clinical data, Charcot offered his diagnoses: "Deb." suffered from a deep and irreparable rupture of the brachial nerves resulting directly from a severe blow to the arm. In contrast, "Porcz."'s was a case of "psychic paralysis". ${ }^{148}$ It was a rare nonconvulsive monosymptomatic hysteria brought on by the emotional aftermath of the carriage accident and patterned perhaps on an attack of articular rheumatism in the knee that ten years earlier had left the patient with a slight limp. ${ }^{149}$

If the classic sensorimotor symptoms occupied pride of place in the Charcotian model of hysteria, the most familiar and flamboyant expression of the disorder was of course the hysterical attack. Charcot did not believe the presence of a seizure necessary for the diagnosis of a case as hysterical. Over a third of his male patients exhibited no convulsive behaviours at all. ${ }^{150}$ However, when an attack did occur in

lesson 8, pp. 152-62; hysteria and multiple sclerosis, ibid., pp. 162-71; and hysteria and Graves' disease, ibid., lesson 11, pp. 231-43.

147 'Sur deux cas de monoplégie brachiale hystérique de cause traumatique chez l'homme (1 and 2)', $L M S N$, vol. 3, lectures 20-21, pp. 299-333.

148 Charcot explored this idea further in 'Les paralysies psychiques', Rev. Hypnotisme exp. thér., March 1888, 2(9): 275-6.

149 For another showpiece of differential diagnostics among Charcot's cases of male hysteria-this one involving organic and hysterical hemiplegias - see the stories of "S." and "O." in Leçons du mardi, vol. 1, lesson 18 , pp. $338-43$ and ibid., lesson 20 , pp. 378-87.

150 See my remarks regarding the proper placement of the hysterical attack in Charcot's overall theory of hysteria in Micale (1990), op. cit., note 4 above, pp. 82-4. 


\section{Charcot and the idea of hysteria in the male}

male patients it tended to be most dramatic- "a sort of storm in the hysterical atmosphere", as one doctor described it ${ }^{151}$-and Charcot was convinced that it followed the same pattern as those in female hysterics. The School of the Salpêtrière was well-known for its highly schematized model of the hysterical fit. The grande attaque commenced with a series of bizarre premonitory symptoms, the aura hysterica, which included light-headedness, a throbbing in the temples, a feeling of constriction of the head, and the globus hystericus or sensation of a lump in the throat. ${ }^{152}$ After the hysterical aura, the paroxysm proper began. According to the Charcotian representation, the grande crise hysterique in its pure form consisted of four stages: an epileptoid period marked by tonic and clonic muscular spasms; a stage of grands mouvements, in which the patient assumed striking and stylized postures, such as the arched pelvis position; a phase of attitudes passionnelles, characterized by the hallucinatory re-enactment of emotional scenes from the patient's past; and a lengthy and delirious period of withdrawal. ${ }^{153}$ Charcot's writings include many graphic descriptions of hysterical attacks undergone by male patients (figures 2 and 3). Here, for instance, he narrated the first two stages of a seizure experienced by "Gui.":

The patient then loses consciousness completely, and the epileptoid period begins. First, the trembling of the right hand increases and is thrown forward, the eyes are convulsed upwards, the limbs are extended, the fists clenched and then twisted in exaggerated pronation. Soon the arms come together in front of the abdomen in convulsive contractions of the pectoral muscles. After this follows the period of contortions, characterized chiefly by extremely violent movements of salutation which are intermingled with incoherent gesticulations. The patient breaks or tears everything he can get his hands on. He assumes very bizarre postures and attitudes, the sort that I have proposed referring to as the "clownism" of the second period of the attack. From time to time, the contortions described above stop for a moment and give way to the distinct position of the arc de cercle. This sometimes involves a true opisthotonos, in which the loins are separated from the plane of the bed by a distance of more than fifty centimetres, with the body resting on the head and heels. At other times, the arching is made in front, the arms crossed over the chest, legs in the air, and the trunk and head lifted upwards, with the back and buttocks alone resting on the bed. ${ }^{154}$

The attacks in Charcot's male patients appeared in all shapes and sizes. Fits could come on slowly or suddenly, and they developed singly or successively. The duration of the attack ran from 30 seconds to 30 minutes. In some cases, the fit was mild while in others, such as "Gui.', s, the patient was violent and acrobatic, requiring physical restraint. $^{155}$

${ }^{151}$ Paul Fabre, 'De l'hystérie chez l'homme', Gaz. méd. Paris, 3 Dec. 1881, 3(49): 867.

152 Ten of Charcot's male patients, or 16 per cent, reported the sensation of the hysterical boule.

153 The most detailed portrait of the Salpêtrian attack, including many cases in men, may be found in Paul Richer, Études cliniques sur la grande hystérie ou l'hystéro-épilepsie, 2nd rev. and enl. ed., Paris, Delahaye \& Lecrosnier, 1885. From Charcot's writings, see 'Description de la grande attaque hystérique' (1879) in Oeuvres complètes, op. cit., note 29 above, vol. 1, pp. 435-48 and Jean-Martin Charcot and Paul Richer, Les démoniaques dans l'art, Paris, Delahaye \& Lecrosnier, 1887, pp. 96-106.

${ }^{154}$ Op. cit., note 50 above, p. 275 , with illustrations on pp. 276-8.

155 The best examples of hysterical fits in males appear in the six cases of lectures 18 and 19 in LMSN, vol. 3, pp. 253-98. See also the case of Henri Hérié in the Archives de l'assistance publique. Salpêtrière, Registre de diagnostics, 6-R-90. 


\section{Mark S. Micale}

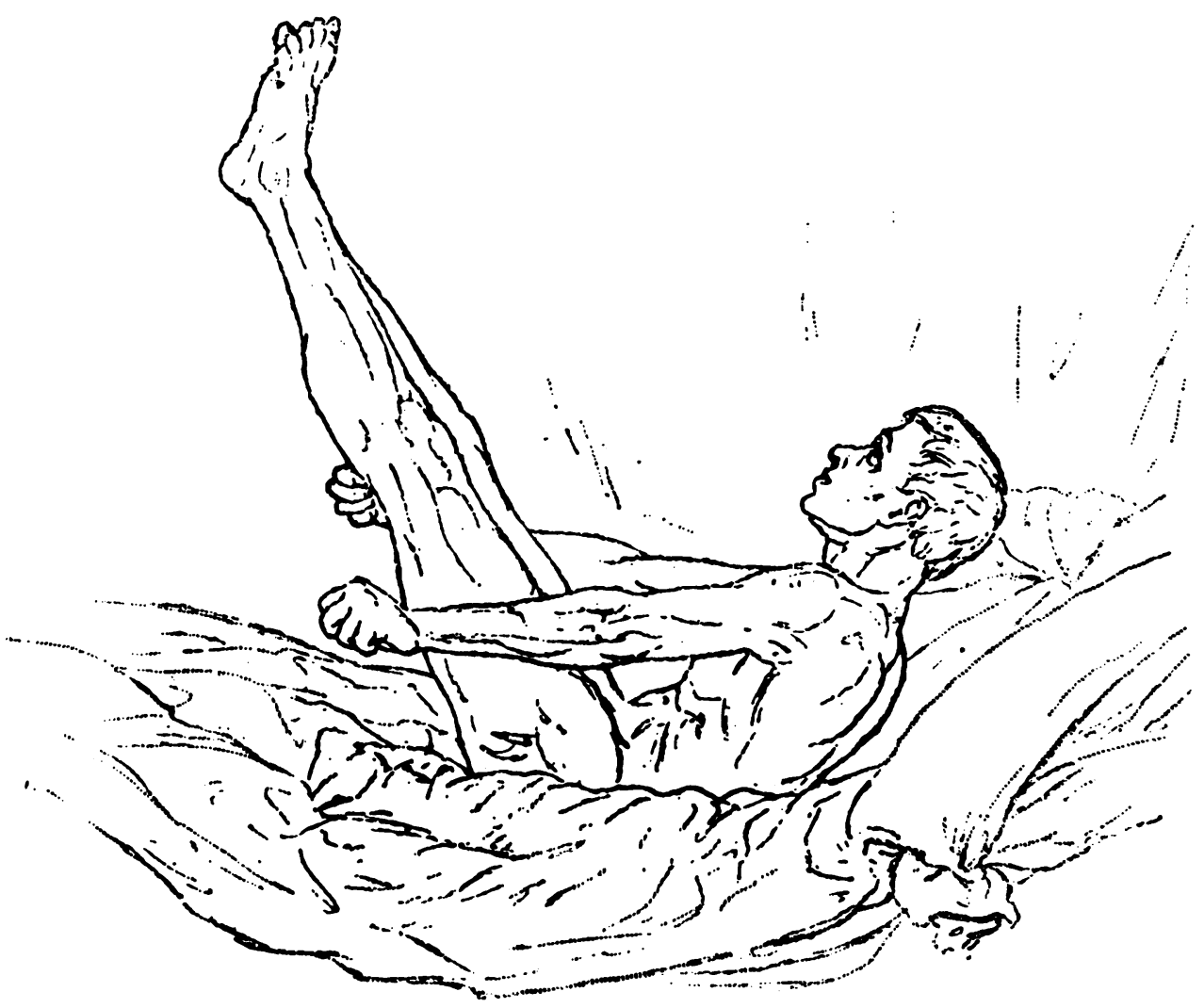

Fig. 87. - Arc de cercle. Emprosthotonos.

Figure 2. Positions of the hysterical attack: Arc de cercle. From Charcot's Leģons du mardi, vol. 2 (1889), p. 427. (Photograph: Wellcome Institute Library, London.)

The final component of Charcot's symptomatological model concerned the curious, colourful concept of the "hysterogenic zone". This was a term that seems to have originated with Charcot, and the idea quickly became a distinguishing feature of the "French" theory of hysteria. ${ }^{156}$ "These zones", Charcot explained more than once, "are more or less circumscribed regions of the body on which pressure or simple

156 The influences on Charcot's formulation of the concept, however, were numerous and varied. They included: demonological psychiatry, with its notion of the sensory stigmati; early French and German sexological literature, which included the notion of the "erotogenic zones" of the body; and the discovery by the neurophysiologist Brown-Séquard in 1869 of a "zone épileptogène" in certain laboratory animals. 


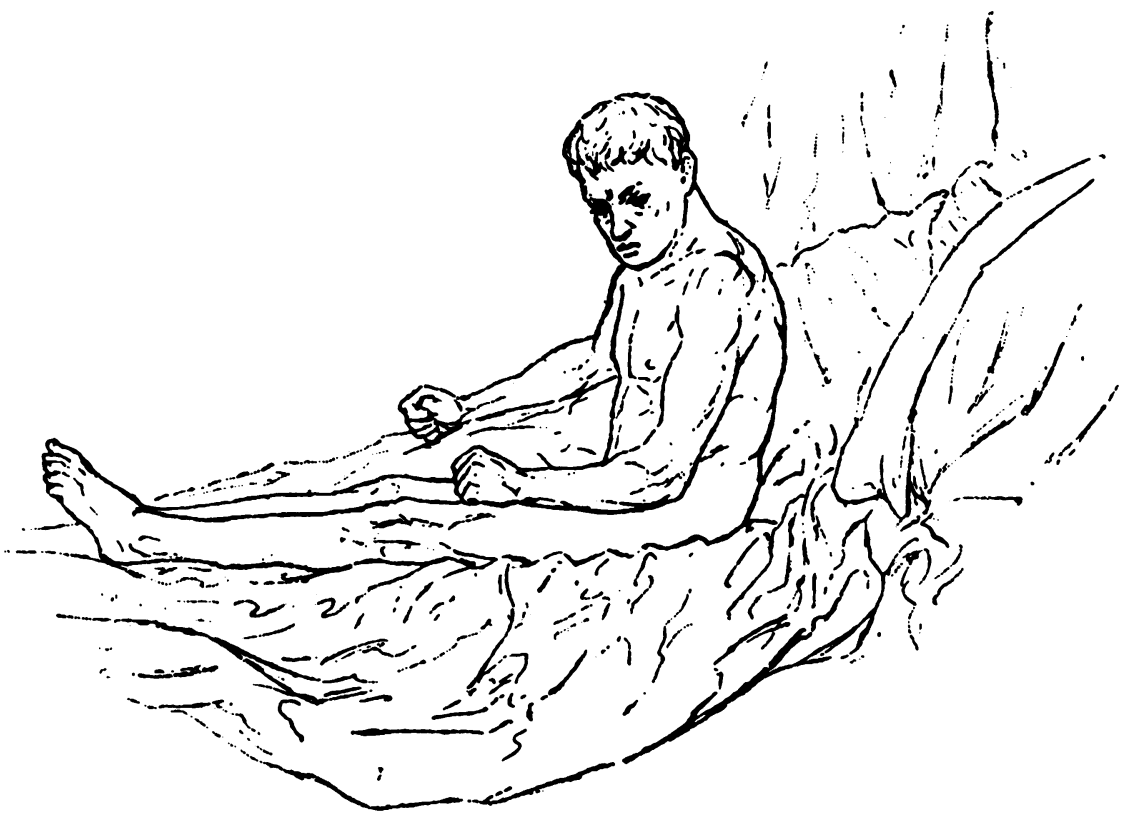

Fig. 88. - Periode der Hallucinationen.

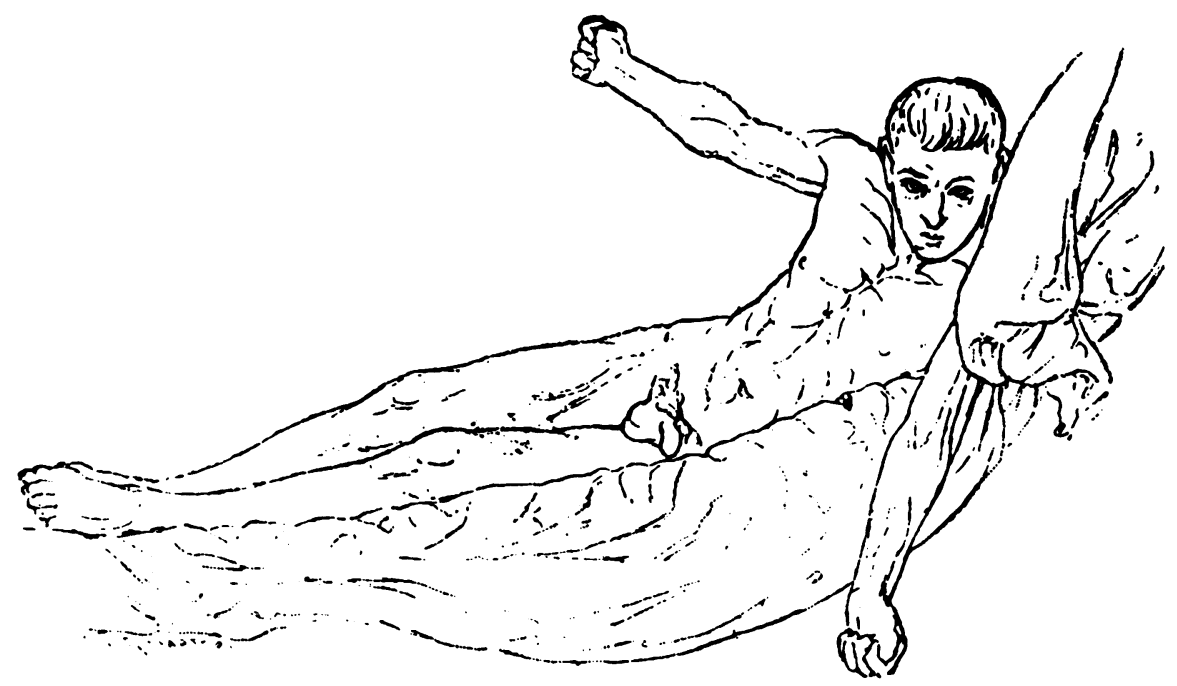

fïz. 8!). - Poriode der llallucinationen.

Figure 3. Positions of the hysterical attack: Hallucinatory period. From Charcot's Leçons du mardi, vol. 2 (1889), p. 428. (Photograph: Wellcome Institute Library, London.) 
rubbing produces quite rapidly the phenomenon of the aura, and which, if you persist, may be followed by the hysterical attack. These points or patches may in addition be the site of permanent hypersensibility and, before an attack, of spontaneous painful irritation." ${ }^{157}$ Hysterogenic points, Charcot found, were usually small, about the diameter of a common coin. They could be set off with friction and pressure or by electrical and magnetic stimulation. The degree of excitability experienced in the zones varied. With a number of Charcot's men, sensitivity was so acute that merely touching, stroking, or breathing on these areas could elicit an attack. ${ }^{158}$ With each patient suspected of the disease, Charcot and his students conducted a thorough clinical examination and drew up body charts with their findings. Forty-eight per cent of Charcot's male patients displayed hysterogenic zones.

Charcot believed that these points excitateurs could be situated anywhere on the human body. With his male patients, they appeared most often on the top of the head, below the clavicle, in the submammary region, at the bottom of the rib cage, across the anterior surface of the body trunk, between the shoulder blades, and in the lumbar and sacral areas. About a quarter of his male patients also presented hysterogenic zones in the pelvic region. Although Charcot rejected uncompromisingly a causal role for the reproductive apparatus in cases of hysteria, he continued to concede the substantial symptomatological involvement of the genitalia in the disorder. This pertained equally to men and women. Accordingly, with several male patients, Charcot found that hysterical fits could be induced with the application of pressure to the groin. Seven of his hysterical males, or 11 per cent, also displayed genital hysterogenic points, along the spermatic cord, on the scrotal skin, or in the testes. ${ }^{159}$ Charcot paid particular attention to the last and regularly examined his patients for exaggerated responses to testicular compression. Of one patient, a 38-year-old railroad employee, he recorded: "The testicle on the left side is more sensitive than the one on the right side. This is a case of testicular as opposed to ovarian hysteria." ${ }^{160}$ In addition, he believed that at times pressure to the testes could arrest or provoke a hysterical attack. "R...eau", for instance, a travelling street-singer (and one of Charcot's three "degenerate" patients) suffered from scattered hyperaesthesias in the iliac and genital regions. "The skin of the scrotum on the left side", Charcot reported, "is very sensitive to the least pressure. The testicle on the same side is still more painful and, if you press either the testicle itself or the tissues surrounding it a little harder, the patient experiences the sensation of something moving from the stomach toward the neck or he feels a sensation of suffocation." 161 In the late nineteenth-

\footnotetext{
157 'De l'hystérie chez les jeunes garçons', $L M S N$, vol. 3, lecture 6, p. 88. See also 'Des zones hystérogènes', Prog. méd., Dec. 1880, 8(51): 1036-8.

${ }_{188}$ Leçons du mardi, vol. 2, lesson 9, pp. 192, 197.

159 See, for instance, $L M S N$, vol. 3, lecture 21, p. 331; Leģons du mardi, vol. 2, lecture 2, pp. 33-4; and the case of "Guénin”, Countway Medical Library, Manuscripts Collection, Charcot, Folio C96.

${ }^{160}$ Leçons du mardi, vol. 1 , lesson 4, p. 63.

161 Ibid., vol. 2, lesson 17, (12 March 1889), p. 401. See the similar descriptions in LMSN, vol. 3, lecture 18, pp. 274-5 and the case of Albert Rose, Bibliothèque Charcot.
} 


\section{Charcot and the idea of hysteria in the male}

century French medical literature on male hysteria, the practices of stopping natural hysterical attacks or eliciting artificial fits through genital manipulation occur very frequently. ${ }^{162}$ The "laying on of hands" of which Michel Foucault has written in regard to the diagnosis and treatment of female hysterics also took place with their male counterparts. ${ }^{163}$

Finally, two of Charcot's male patients exhibited what may fairly be described as a remarkable piece of cross-sexual identification. "D...cy" was a middle-aged worker, originally from the French Caribbean, who had been badly frightened one day when he was nearly struck by lightning during a thunderstorm. A second, unnamed figure, "a peasant of great rusticity", had recently come to Paris to work in a railway station where he was once nearly killed in a freight car accident. In addition to several other sensory stigmata, both men developed unmistakable hysterogenic zones in the area of the lower abdominal wall corresponding precisely to the position of the ovaries in the female body. ${ }^{164}$ Other doctors at the Salpêtrière found similar symptom-formations in their male patients. Gilles de la Tourette was so impressed by this phenomenon that he labelled these areas "les zones pseudo-ovariennes" of the male body. He believed that these points appeared frequently in male hysterics, that they could develop unilaterally or bilaterally, and that they occurred most often on the left side of the body $^{165}$ (figure 4).

This idea, too, has its medico-historical context. Fifteen years earlier, when dealing exclusively with female patients, Charcot "discovered" his first hysterogenic point in the ovaries, and one of his first published case histories of the disorder concerned hysterical ovaralgias. ${ }^{166}$ Charcot at that time cited with partial approbation the writings of the mid-century ovaristes, Piorry, Schutzenberger, and Négrier. ${ }^{167}$ Moreover, he gave credence to the time-worn belief that firm pressure on the female iliac area could halt or lessen a hysterical attack. ${ }^{168}$ We have seen previously that, by the middle of the nineteenth century, traditional uterine theories of hysteria were being challenged, and, in Charcot's mind, challenged decisively. However, at roughly the same time, major advances were being made in understanding the physiology of ovulation. One consequence of this new scientific interest in the influence and operation of the ovaries was the emergence of ovarian theories of hysterogenesis. Now, aetiologically, Charcot rejected these ideas: however, in the realm of symptomatology, and in this new, theoretically updated ovarian version, he accepted a gynaecological view of hysteria. ${ }^{169}$ In the 1880 s, then, as he applied his

162 P. Foet, 'Attaque d'hystérie chez un homme, traitée et guérie par la compression des testicules,' Gaz. hebd. Méd. Chir., 11 Dec. 1874, 11(50): 798; A. Mossé, 'Observations de grand hystérie chez l'hommeCrises convulsives arrêtées par la compression du testicule gauche-État léthargique', Gaz. hebd. Sci. méd. Montpellier, 8 Jan. 1887, 9(2): 13-18; P.-J.-E. Bitôt and J. Sabrazès, 'Anesthésie testiculaire dans l'hystérie mâle', Bull. Soc. Anat. Physiol. Bordeaux, 14 Dec. 1891, 12: 279-81.

163 Foucault, op. cit., note 121 above, p. 75.

164 Leçons du mardi, vol. 2, lesson 19, pp. 454, 456, and 'Des paralysies', op. cit., note 37 above, p. 491.

165 Gilles de la Tourette, op. cit., note 40 above, vol. 1, pp. 299-300.

166 'De l'hyperesthésie ovarienne', $L M S N$, vol. 1, lecture 11, pp. $320-46$.

167 See in particular ibid., 321-30, where he privileged the ideas of these writers over those of Briquet.

168 Ibid., pp. 332-6. See also 'De l'hémianesthésie hystérique', ibid., pp. 301-3.

169 An envelope of materials at the Bibliothéque Charcot is labelled, in Charcot's hand, "Hystérie et ovaires". 


\section{Mark S. Micale}

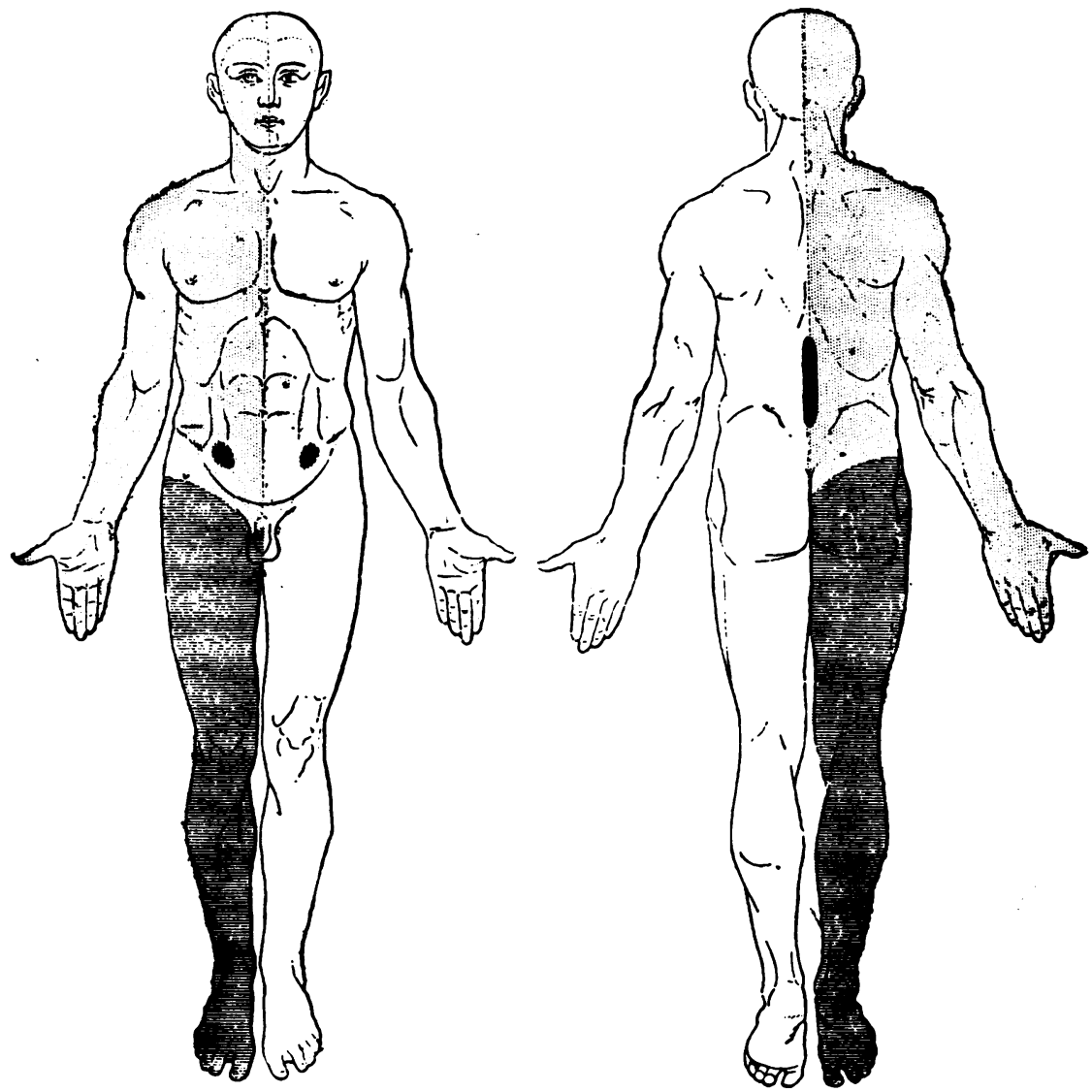

Figf. 19, 20. - 7ones pseudo-ovariennes, zone hystérogène dorsale, hémiancsthrisic et hémihyposthésic à droitc. (G. T.)

Figure 4. Hysterogenic points of the male body: the "pseudo-ovarian zone". From Georges Gilles de la Tourette, Traité clinique et thérapeutique de l'hystérie, vol. 1 (1891), p. 299. (Photograph: Wellcome Institute Library, London.)

model of female hysteria to other categories of patients, we find him extending the concept of ovarian hysterogenic points to males. Despite his self-conscious medical modernism, Charcot's writings, including his work on masculine hysteria, contained residues of classical medical theory.

Whether the points pseudo-ovariens that Charcot located in his male patients reflected the theoretical imaginativeness of the doctor, which was then replicated iatrogenically in patient behaviour; or whether these were creative sympathetic reactions on the part of male patients to their female counterparts, is a matter for 


\section{Charcot and the idea of hysteria in the male}

speculation. ${ }^{170}$ Whatever their origin, it is important to realize that for Charcot and his followers, they were not exotic metaphors for general stomach distress but rather exact anatomical analogues to the female condition. Doctors realized, of course, that these points "correspond to no particular organ" 171 in men. Nevertheless, the source of sensation, they insisted, was internal, not cutaneous. Pseudo-ovarian hyperaesthesias were precisely localized in the male patient and, upon compression, could produce all the symptoms of the hysterical aura and attack. ${ }^{172}$ As one physician at Bicêtre wrote of a man with a persistent spot of pain on the left side of his abdomen, it was "exactly as if there had been an ovary hidden behind the abdominal wall". 173

\section{VI}

Charcot's work on hysterical illness in the male may be understood on various historical levels. I have tried to show the significance of his writings for the intellectual history of hysteria, for the general evolution of Charcot's career, and for present-day neurological and psychological science. However, in conclusion, I would like to pose a different set of questions: How do Charcot's ideas about hysteria in men compare with his ideas about hysteria in women? What can we surmise from these ideas about Charcot as scientific theoretician and about the medical culture of which he was a part? Finally, where does the broad social and cultural significance lie in the sudden, widespread application of the hysteria label to male patients a hundred years ago?

Generally speaking, the picture of hysteria that emerges from Charcot's collected writings is similar for male and female patients. For Charcot, the malady in both sexes was a hereditarian-degenerative disorder of the nervous system with an extensive quasi-neurological symptomatology, a volatile pattern of evolution, and a largely unfavourable prognosis. Many times, Charcot insisted on the essential congruence of hysterical disorders in the two sexes. ${ }^{174}$ However, it would be naive to

170 The second possibility deserves consideration. Included in the nineteenth-century medical literature are also a number of cases of pseudocyesis, or hysterical pregnancy, in men. These male Anna O.'s tended to develop their symptoms - which involved faintness, morning nausea, leg cramps, and, in one case, a large tympanitic swelling of the abdomen-during the pregnancies of their wives or mistresses. See Silas Weir Mitchell, Lectures on diseases of the nervous system, especially in women, 2 nd rev. and enl. ed., Philadelphia, Lea Brothers, 1885, pp. 63-4; Francis W. Clark, 'Hysteria in men', J. ment. Sci., Jan. 1888, 33(144): 545; and Griesinger, op. cit., note 27 above, p. 186.

171 Gilles de la Tourette, op. cit., note 40 above, vol. 1, p. 300.

172 In Charcot's writings on men, I have found no counterpart to his use with women of the ovarian compressor, a mechanical apparatus for preventing attacks through continual pressure on a hyperaesthesiac ovary. However, consider the case of Pierre de Bassonnière, who suffered from a case of cryptorchism. Charcot had constructed a special inguinal belt to hold the boy's testicle in place in order to prevent hysterical seizures (case of Pierre de Bassonnière, Archives de l'assistance publique, Salpêtrière, Registre de diagnostics, 6-R-90).

${ }_{73}$ M. D'Olier, 'De la coexistence de l'hystérie et de l'épilepsie ... considerée dans les deux sexes et en particulier chez l'homme', Anns méd-psych., series 6, Sept. 1881, 6: 196. For a British statement of this idea, see Thomas Savill, 'Case of hysteria minor with "ovarian phenomena" in a male subject', Lancet, 11 May 1889 , pp. 934-5.

${ }^{174} L M S N$, vol. 3, lecture 6, p. 89; ibid., lecture 18, pp. 253-4; Leçons du mardi, vol. 2, lesson 5, p. 96; and Charcot and Richer, op. cit., note 153 above, p. 91 . This point was also emphasized by Georges Guinon in 'L'hystérie chez l'homme comparée à l'hystérie chez la femme', Gaz. méd. Paris, 16 May 1885, 56(20): 231-4. 
claim that his work represented only the direct application of an ancient and unchanged diagnostic category to a new clinical population. Rather, on close inspection, we find a complex series of resemblances and differences in Charcot's medical thinking about men and women. In order to understand these relationships, it is useful to consider Charcot's picture of the disease in its component parts.

Charcot posited a primary constitutional origin for hysteria in both sexes. In its basic design, his ideas regarding the hereditary origins of the "functional" nervous disorders were identical for men and women. However, in applying a general Morelian model of nervous disease to hysteria, Charcot formulated two sub-concepts that were conspicuously unalike for males and females. Statistically, women remained far more prone to the disorder than men (the 1:20 ratio), and women served as the sole parental agents of direct transmission of hysteria to their sons. Both of these beliefs, it seems to me, reflect the enduring belief that au fond hysteria remained a female affliction.

The greatest area of theoretical divergence between male and female hysteria concerned the secondary causes. The many agents provocateurs of hysteria were circumstantial and proved more open than constitutional causes to the reflection of subjective, "nonscientific" factors. In most of Charcot's cases involving women, a hereditarily tainted individual became sick, that is, actually "went hysterical", as the result of an overpowering emotional experience. Most common among these experiences, in order of frequency, were: 1) marital turmoil, 2) unrequited love, 3) religious ecstasy, 4) superstitious fear, and 5) death of a family member. These cases most often took place in domestic settings. By contrast, Charcot's adult male patients generally developed hysteria following a physically traumatic event, usually one in the workplace, and the disorders were often compounded by prior venereal infection or alcoholic excess. Conversely, Charcot's writings on traumatic hysteria only occasionally dealt with female patients, and it is rare for his male cases to occur outside the context of a direct bodily threat. When hysteria in males was precipitated by a purely emotional force, it was elicited most often by such "manly" emotions as rage, jealousy, and agitation. In other words, Charcot, knowingly or unknowingly, formulated for the two sexes an essentially separate set of secondary causal factors that were consonant with prevailing notions of masculine and feminine natures. Plainly stated, women in his writings fell ill due to their vulnerable emotional natures and inability to control their feelings, while men got sick from working, drinking, and fornicating too much. Hysterical women suffered from an excess of "feminine" behaviours, hysterical men an excess of "masculine" behaviours. ${ }^{175}$

We can detect a gender-specific pattern in other areas of Charcot's thinking, too: consider the model of symptomatology. Charcot's writings on hysteria are often more noteworthy for what they exclude than include. As some readers may have noticed, Charcot provided remarkably little information about the mental state of his male patients. By and large, his case histories involving men are dense, technical narratives of the somatic, especially neurological, symptoms of the disorder with little reference

\footnotetext{
175 It is important, however, to be qualified on this point. As the case of "Pasq." mentioned above demonstrates, there were exceptions to this distribution of causes.
} 


\section{Charcot and the idea of hysteria in the male}

to matters psychological. With his female patients, neurological description was also paramount; but here the physical manifestations were typically accompanied by symptoms such as extravagant mood shifts, attacks of anxiety, fits of crying, and threats of suicide. Such unseemly emotional self-displays only occasionally complicate Charcot's cases of hysteria in males. If Charcot reported an extreme mental condition in a male patient, this was nearly always depression. In those instances where he acknowledged more subtle psychological phenomena, including as sensitive sexual symptoms, he was likely to discuss the case under the mixed diagnostic label of "hystero-neurasthenia". ${ }^{176}$ In the 61 published case histories, there are only two instances of an adult man crying. ${ }^{177} \mathrm{~A}$ number of times, Charcot openly acknowledged these emotional differences between the disorder in the two sexes. He claimed, for instance, that male victims of hysterical illness displayed a greater degree of "symptomatological fixity" than female patients, that is, the physical manifestations of their hysterias tended to be stable and persistent, sometimes even permanent, whereas in women they were capricious and short-lived. ${ }^{178}$ Mood and personality were often distinct too: "The hysterical men of the working class who ... fill the hospital wards of Paris today", he noted in 1888, "are almost always sombre, melancholic, depressed, and discouraged people ... We should not expect to find in the male that morbid brio frequent in reality in the female." 179 Charcot, then, seems to have limited his account of male hysteria to the most "objective", externalized aspects of the disorder while ignoring or downplaying symptoms we would today call psycho-neurotic. It should be noted that it is these dramatically psychological aspects of hysteria that are accounted for in current psychiatric terminology under the heading of "hysterical" or "histrionic personality type" and that represent the most stereotypically feminine features of the disorder.

We can get a closer view of Charcot's de-emotionalization of the hysteria diagnosis with male patients by examining a single element of his symptomatological model. In his descriptions of the hysterical attack in women, Charcot devoted roughly equal time to the four stages of the fit. Among these stages, the third phase, of attitudes passionnelles, was the most intense psychologically-a long and breathless performance during which patients rehearsed in words and actions painful emotional scenes from their pasts. In the Salpêtrian literature on female hysteria, this aspect of the attack received extensive documentation: fear, ecstasy, surprise, pleasure, and religious enthusiasm, for example, were depicted time and again in the Iconographie photographique. However, with Charcot's male patients, the range of emotions expressed in this third stage was noticeably narrower, and it tended decidedly toward the darker, depressive end of the spectrum. One medical observer

176 Leçons du mardi, vol. 1, lesson 4, pp. 62-5; ibid., vol. 2, lesson 7, pp. 131-9.

177 Ibid., lesson 6, pp. 124-5; ibid., lesson 19, pp. 456-457.

178 Ibid., Appendix I, p. 533. One result of the increased stability of the disorder in men, Charcot contended, was its greater therapeutic recalcitrance: "Chose singulière, cette hystérie de l'homme, bien différente, à certains égards, de celle de la femme . . . semble être beaucoup plus grave et comporter avec elle un pronostic infiniment plus sérieux”: 'Des paralysies hystéro-traumatiques chez l'homme', Sem. méd., 1887 , p. 491 . Male/female differences in theory, we see here, did not always favour men.

179 Leçons du mardi, vol. 2, lesson 3, p. 50. 


\section{Mark S. Micale}

remarked aptly in 1885 that "The characteristics of the attack in him [the male patient] present, as is usual, some differences from what is observed in the female. In the latter, there is a happy phase and a sad phase in the passional period, whereas in the male all the sentiments are sad and sombre. Everything in him has a terrifying character, which is moreover the standard psychical condition in these patients, while the contrary is found in the female." 180 Moreover, in several cases involving males, the period of attitudes passionnelles was shortened or truncated, and in a substantial number- 25 cases, or 41 per cent-this stage was absent altogether. ${ }^{181}$ In place of its exaggerated emotionality, we read much more in the clinical reports on men about the first, epileptiform stage of the attack. The pattern is again clear. The diagnosis has been drained of its affective content and the most physically extroverted aspects of the disorder predominate over subjective states of mind and emotion. Simplifying somewhat, we can say that the distinction between male hysteria and female hysteria in Charcot's work is the difference between a neuropathological and a psychopathological interpretation of the disorder. Indeed, it may well have been precisely because he formulated a highly neurologized model of hysteria that Charcot was able to apply the hysteria concept to members of his own sex with such ease and that his professional male contemporaries, after centuries of defensive rejection, were willing from the first to accept this with relatively little reluctance.

However, I have come to believe that, when considered in the context of hysteria's long history, the most striking feature of Charcot's commentary on the disorder in men concerns not the phenomenon of difference/différence, but sameness. Let me elaborate. For virtually millennia, hysteria, "la maladie de la matrice", had been seen as a pathology of femininity whose diagnosis served as a kind of medical metaphor for everything that male observers found mysterious or unmanageable in the opposite sex. However, in the final quarter of the nineteenth century, the premier theoretician of the disorder formulated a full-blown theory of the disorder in the male sex. He devoted 15 years of his career to a scientific investigation of the topic, illustrated his ideas with dozens of clinical histories, and advanced the theory with the full weight of his professional authority. Several components of Charcot's model of male hysteria remained specific to the gender. But what is perhaps more suprising is how scattered and limited were these theoretical asymmetries. Furthermore, at a time when definitions of the disorder were pre-eminently nosographical, the Charcotian clinical constructions of the diagnoses of male and female hysteria were strikingly alike.

At one time or another, Charcot located virtually the entire range of physical behaviours from past conceptualizations of female hysteria in men too. The sensation of globus hystericus in the throat, which the ancients had believed resulted from the pressure of a mobile womb on other organs of the body cavity, appeared regularly in Charcot's male patients. The anaesthesias and hyperaesthesias that formed so

\footnotetext{
180 Paul Lucas-Championnière, 'Hospice de la Salpêtrière: hystérie chez l'homme', J. Méd. Chir. Prat., Oct. 1885, 56: 445 .

${ }^{181}$ For hysterical attacks in males lacking the third passional period, see the cases of "Gui" ( $L M S N$, vol. 3, lecture 18, pp. 278, 281); "Laf...cque” (Lȩ̧ons du mardi, vol. 2, lesson 12, pp. 265-9); "Lap...sonne” (ibid., lesson 17, pp. 393-9); and "P...eyn" (ibid., lesson 21, pp. 518-23).
} 


\section{Charcot and the idea of hysteria in the male}

copiously in Charcot's male hysterics may be seen as secularized and scientized versions of the stigmati diaboli of witches in the sixteenth and seventeenth centuries. For generations the hysterical attack had been interpreted synecdochically, as a sort of bodily symbolism for childbirth, the female orgasm, and feminine nature generally. In the late nineteenth century, the attack was described frequently, and identically, in men. And, in what is surely the ultimate equation of the two sexes, hysterical pain in the female organ believed to most differentiate women from men-the ovaries-was attributed in Charcot's writings directly to men. The dramatic diagnostic rapprochement between the sexes represented by Charcot's work on male hysteria, then, was not achieved through a wholesale masculinization of the hysteria concept. It was accomplished rather through the transposition, at times with remarkable anatomical literalness, of a very old and gynocentric model of sickness onto members of the male population. ${ }^{182}$

Finally, Charcot's selective equalization of the hysteria diagnosis between the sexes requires placement in the larger setting of nineteenth-century society and culture. Throughout the Victorian era, the official distribution of physical and behavioural characteristics, sexual and familial roles, and social and economic activities between men and women was, by earlier and later standards, highly polarized. According to this system, the "masculine" was defined by such personal attributes at strength, logic, rationality, independence, productivity, and emotional self-confidence. By contrast, women were believed to embody the traits of dependency, sensitivity, impressionability, domestic virtue, and affective over cerebral modes of perception. Based on the dominant sexual ideology of the day, these two sets of human qualities never naturally overlapped in an individual of either sex. ${ }^{183} \mathrm{By}$ and large, the major theorists of human nature, in the nineteenth century and before, endorsed this outlook through the postulation of fundamentally separate biologies and psychologies of the sexes. ${ }^{184}$

However, during the last 120 years or so, the Victorian doctrine of "separate spheres" has been challenged across the board. Most visibly, the dissolution of the old

\footnotetext{
182 In the future, we will require in science and gender studies a historiographical model that accounts equally for the relative differences and similarities of the sexes in past theoretical systems and for their combined historical significance. For more on this point, refer to Mark S. Micale, 'Hysteria male/hysteria female: reflections on comparative gender construction in nineteenth-century France and Britain' in Marina Benjamin (ed.), Science and sensibility: essays on gender and scientific enquiry, 1780-1945, Oxford, Basil Blackwell, forthcoming.

${ }^{183}$ A great deal, of course, has been written on this theme over the last twenty years by British and American social and cultural historians. For a sampling of the literature, consult the essays in two collections, Suffer and be still: women in the Victorian age, Bloomington, Indiana University Press, 1973, and $A$ widening sphere: changing roles of Victorian women, Bloomington, Indiana University Press, 1977, both edited by Martha Vicinus, as well as Carl N. Degler, At odds: women and the family in America from the revolution to the present, New York, Oxford University Press, 1980, and Peter Gay, The bourgeois experience: Victoria to Freud, vol. 1, Education of the senses, New York, Oxford University Press, 1984. Some recent and thoughtful revisionist reflections on the subject may be found in $\mathbf{M}$. Jeanne Peterson, Family, love, and work in the lives of Victorian gentlewomen, Bloomington, Indiana University Press, 1989.

184 Elaine Showalter has written in this regard that English and European psychiatries of the nineteenth century were "built on an ideology of absolute and natural difference between men and women" (op. cit., note 6 above, pp. 167-8).
} 
"sex/gender system" 185 has involved women fighting for the rights, privileges, and opportunities formerly reserved for men. The struggle of women for the vote, for entrance into the wage-labour force, and for admission into professional schools were heroic episodes in this historical experience, and over the past two decades, scholars have documented these events thoroughly. Moreover, historians have by now demonstrated conclusively that Victorian doctors very often played a conservative, if not outright oppositional, role in the debates on such questions as women's work, women's education, or divorce rights for women. ${ }^{186}$

However, these important changes have not only involved fundamental shifts in the definition of femininity, but also of masculinity; and, furthermore, the professional medical classes of the nineteenth century were implicated in the process very diversely. The decline of the sexual division of labour has at times also involved men engaging in the traditional pursuits or taking on characteristics and social roles conventionally reserved for woman. Criticism of a prevailing gender ideology may originate from within mainstream professional bodies as well as from disempowered social groups. And the decline of the separate spheres of Victoria's time has been characterized not only by the escape of women from extreme, caricatured gender roles but by the progressive approximation of the concepts of masculinity and femininity in many areas of society and thought.

The present essay illustrates at once both aspects of these processes. In the end, Charcot's oeuvre on hysteria bears a highly ambiguous relationship to the contemporary socio-sexual system. In the Iconographie photographique of the seventies, Charcot and his students created some of the most gender-stereotyped images of their century, and they did so specifically through the visual representation of hysteria in females. However, a decade later, Charcot's bringing of the hysteria diagnosis to the male sex-his "hysterization of men's bodies"-offered a direct challenge to the gender-differentiated psychologies of the time. ${ }^{187}$ Conducted after the work on women, and conceived under different social, scientific, and professional circumstances, Charcot's work on masculine hysteria carried, for both science and society, a liberalizing potential. The highly stylized mid-Victorian delegation of physical and emotional characteristics - female sickness, fragility, and frivolity versus male sanity, strength, and self-control-was here modified, and in this instance by a group of physicians at the heart of the medical establishment. A process of a kind of gender relativization was in operation, not only in regard to social, economic, and

\footnotetext{
185 I believe that Gayle Rabin was the first person to discuss the concept of a "sex/gender system" in "The traffic in women: notes on the "political economy" of women', in Rayna Reiter (ed.), Toward an anthropology of women, New York, Monthly Review Press, 1975, pp. 157-210.

186 Degler, op. cit., note 183 above, chs. 9-11; Brian Harrison, Separate spheres: the opposition to women's suffrage in Britain, London, Croom Helm, 1978, ch. 4; Susan Sleeth Mosedale, 'Science corrupted: Victorian biologists consider "the woman question" ', J. Hist. Biol., 1978, 11: 1-55; John S. Haller, Jr. and Robin M. Haller, The physician and sexuality in Victorian America, Chicago, University of Illinois Press, 1974, ch. 2; Carroll Smith-Rosenberg and Charles Rosenberg, 'The female animal: medical and biological views of woman and her role in nineteenth-century America', J. Am. Hist., 1973, 60: 332-56.

${ }^{187}$ Foucault wrote of the "hystérisation du corps de la femme" in the introductory volume of his Histoire de la sexualité, op. cit., note 121 above, p. 137.
} 


\section{Charcot and the idea of hysteria in the male}

political behaviours in public settings but in the realm of private medical pathologies. The means and methods for interpreting the two sexes in hospitals, in doctors' offices, and in out-patient clinics-literally the ways in which men and women were seen to be sick-were also drawing closer together. By bringing a very old diagnostic category with a strong single-sex association to the second half of the population, Charcot and his followers were contributing to a process of gender liberalization that was beginning to change the social world around them and that, in ways they could scarcely have conceived, has continued to do so in the present century. ${ }^{188}$

\footnotetext{
188 It may be noted that in the public arena too the 1880s in France was a period of accelerated gender relativization. The movement for the enfranchisement of women, under the leadership of Hubertine Auclert, reached an organized and militant form during this decade, and the conseil général of the Seine voted on the suffrage issue a number of times. With passage of the Camille Sée Law of 1880, women achieved access to a system of free secondary schooling. And, in 1884, a long and acrimonious debate over the legal rights of women to divorce led to the Naquet Law. Perhaps most pertinent were developments in the field of medical education. The first Frenchwoman to receive a doctorate in medicine was granted her degree by the Paris Medical Faculty in 1875. Women went on to compete for positions as externes in 1881 and internes in 1885 . Needless to say, these developments aroused in turn a reaction to reinforce traditional gender distinctions.
} 